\title{
CROATIA AND TURKEY - COMPARISON OF TWO MEDITERRANEAN TOURIST DESTINATIONS
}

\author{
Hilâl Numanoğlu ${ }^{1}$ \\ Fran Poljak ${ }^{2}$ (1) \\ Gordi Sušić ${ }^{3}$
}

DOI: https://doi.org/10.31410/tmt.2020.185

\begin{abstract}
The paper evaluates tourism sector dynamics and tourism development strategies of two Mediterranean countries, Croatia and Turkey. In order to identify key supply and demand characteristics of this sector various indicators are graphically presented, elaborated and explained, from accommodation facilities available to physical and financial tourism indicators, their contribution to real activity and employment, as well as price competitiveness determinants. The goal of the paper is to outline similarities and differences in tourism sector indicators, as well as the way Turkey and Croatia see their tourism activity (preferably) developing in the future. Paper is of value added to academic scholars, tourist/business specialists, macroeconomic analysts and broad domestic and international readers interested in this field of research.
\end{abstract}

Keywords: Croatia's tourism developments, Turkey's tourism developments, Physical tourist indicators, Financial tourist indicators, Price competitiveness, Tourism development strategy.

\section{INTRODUCTION}

$\mathrm{T}$ his paper aims to evaluate and compare tourism sector dynamics and development strategies of two Mediterranean countries, Croatia and Turkey. To grasp the key defining characteristics of supply and demand, various indicators in this segment of real activity are graphically presented, elaborated and explained, from assets available and employed, to physical and financial indicators, as well as factors that affect price competitiveness. The paper also presents the defining characteristics of tourism development strategies of two respective countries. The paper aims to outline similarities and differences in tourism sector indicators (positive aspect), as well the way Turkey and Croatia see the industry (preferably) developing in the future (normative aspect). As such, the paper is of value added to academic scholars, tourism/business specialists, macroeconomic analysts and broad domestic and international readers interested in this topic.

The paper encompasses eight parts. Part 1 pertains to introductory statements and is followed by part 2 that outlines key geographic characteristics of analysed countries, their tourism origins and dominant tourism approaches. Part 3 covers Croatia's and Turkey's tourism supply side indicators pertaining to standard accommodation establishments, number of available beds in them, as well as numbers of airports, marinas and golf courses. Part 4 covers respective countries' supply side indicators: yearly and intra-year distribution of arrivals and nights spent by foreign tourists, as well as the country of residence, means of transportation and type of accommodation distributions. Part 5 covers the tourism sector contribution to real and labour market indicators in Turkey and Croatia. Part 6 deals with competitiveness issues related to movements

\footnotetext{
1 Zagreb School of Economics and Management (ZSEM), Vukasovićeva ulica 1, Zagreb, Croatia

2 Zagreb School of Economics and Management (ZSEM), Vukasovićeva ulica 1, Zagreb, Croatia

3 Zagreb School of Economics and Management (ZSEM), Vukasovićeva ulica 1, Zagreb, Croatia
} 
in nominal exchange rates (EUR/HRK and EUR/TRY), inflation (measured by consumer price index, CPI) and real effective exchange rates of respective countries (deflated by CPI). Part 7 is oriented towards the future and elaborates on countries' main tourism development strategies goals. Part 8 concludes by summarising the main findings of the paper.

\section{KEY GEOGRAPHIC CHARACTERISTICS OF CROATIA AND TURKEY AND THEIR TOURISM ORIGINS}

Both Mediterranean countries, Croatia and Turkey differ in geographic location and size, their historic and cultural identity. In the next few sentences, the geographic characteristics of both countries will be briefly outlined, as well as respective countries' tourism origins and dominant tourism approaches.

\subsection{Croatia at a Glance}

Croatia is both Mediterranean and continental Central and South-East European country. To the west, it shares borders with Slovenia and (maritime border with) Italy, Hungary in the north, Serbia and Bosnia and Herzegovina in the east, and Montenegro in the south. Croatia is a relatively small country covering around 56,000 square kilometres. Its coastline is long and dotted with more than thousand islands, islets, stacks and reefs.

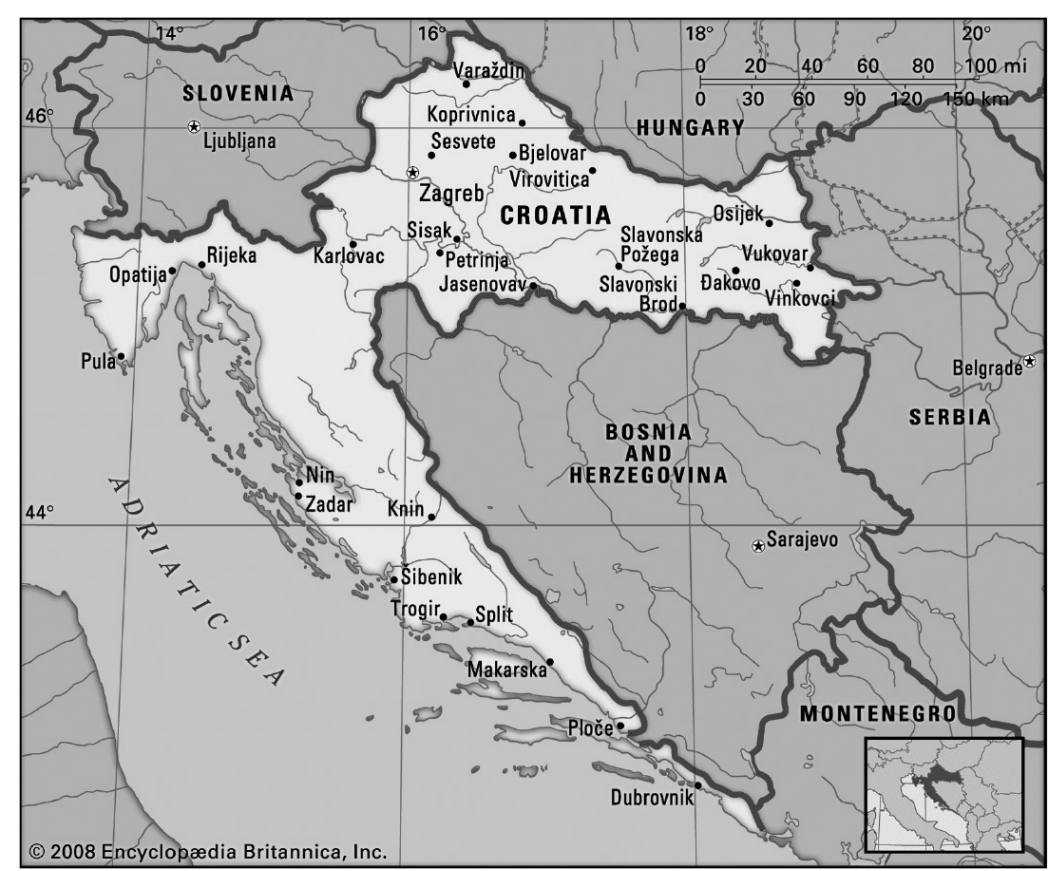

Picture 1. Map of Croatia

Source: britannica.com

The country boasts with ten cultural and natural sites inscribed in the UNESCO World Heritage Sites list (the cultural sites consist of the Episcopal Complex of the Euphrasian Basilica in the Historic Centre of Poreč, Historic City of Trogir, Historical Complex of Split with the Palace of Diocletian, Old City of Dubrovnik, Stari Grad Plain, Medieval Tombstone Graveyards in Stećci, The Cathedral of St James in Sibenik, Venetian Works of Defence between the 16th and 17th Centuries, while the two natural sites inscribed in the UNESCO World Heritage list are Plitvice Lakes National Park and Ancient and Primeval Beech Forests of the Carpathians and 
Other Regions of Europe). The capital of Croatia and its largest city, Zagreb, a growing tourism destination itself in recent years, is located in the northwest part of Croatia with a population of about 800,000 people.

The beginnings of Croatian tourism date back to the beginning of the $19^{\text {th }}$ century when coastal towns, notably Opatija, (then part of the Austro-Hungarian Empire), became destinations for health tourism. In the ' 60 s and ' 70 s of the last century, Croatia saw a big increase in (mass) tourism infrastructure with hotels, resorts and marinas being built along the coastline, whose construction was initialised and supported by central and/or local socialist government (Orsini and Ostojić, 2018). During the early '90s, tourism in Croatia was affected by the War for Independence, after which the country positioned itself as an established and esteemed tourism destination on the Mediterranean market (Orsini and Ostojić, 2018). Croatia's membership in the European Union brought new (foreign and domestic) investment in the tourism sector expanding both the quantity and quality of its supply.

Along the Adriatic Sea littoral, the main form of tourism is the classical sun-and-sea format, with health, congressional and golf tourism shares lagging behind some other Mediterranean competitors.

\subsection{Turkey at a Glance}

Turkey is a country that binds together Europe and Asia, with three percent of the country's landmass situated in Europe. The dominant, Asia located part of the country can be seen as a big peninsula, surrounded by the Black Sea in the north, by the Sea of Marmara and the Aegean Sea in the west, and by the Mediterranean Sea in the south. The country borders Greece and Bulgaria on the west, Georgia, Armenia, Azerbaijan and Iran on the east, Syria and Iraq on the south. Total area of the country is approximately 780,000 square kilometres with more than eight thousand kilometres of coastline.

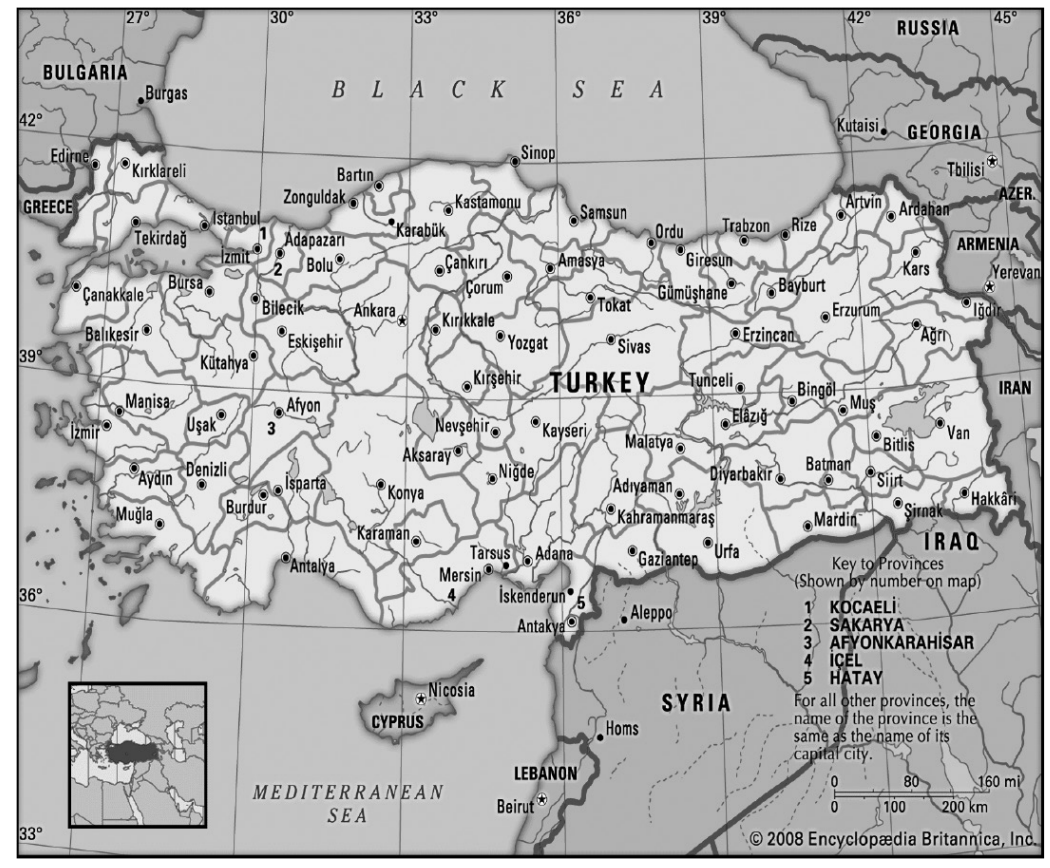

Picture 2. Map of Turkey

Source: britannica.com 
Turkey is proud of 18 cultural and mixed natural places inscribed on the UNESCO World Heritage Sites list (Aphrodisias, archaeological site of Ani, archaeological site of Troy, Bursa and Cumalıkızık: the birth of the Ottoman Empire, City of Safranbolu, Diyarbakır Fortress and Hevsel Gardens Cultural Landscape, Ephesus, Göbekli Tepe, Great Mosque and Hospital of Divriği, Hattusha: the Hittite Capital, Historic Areas of Istanbul, Nemrut Dağ, Neolithic Site of Çatalhöyük, Pergamon and its Multi-Layered Cultural Landscape, Selimiye Mosque and its Social Complex, Xanthos-Letoon as well as, Göreme National Park and the Rock Sites of Cappadocia and Hierapolis-Pamukkale). Its capital city is Ankara, with a population of 5.1 million, though Istanbul (15.2 million inhabitants) is globally renowned as Turkey's historic, commercial, (air) travel and tourist hub.

The tourism sector of Turkey was not developed extensively until the 1980s. With "January 1980 Decisions", liberalisation steps were undertaken, and ensuing structural reforms and neo-liberal policies encouraged foreign investment (Esen and Uyar, 2016). In 1982 "Law for the Encouragement of Tourism" was implemented, regulating and further promoting the tourism sector of the country (lawsturkey.com; 1982). A year later, "Turkish Civil Aviation Law" fostered development of the air travel industry and allowed the private sector to operate in the aviation field (lawsturkey.com; 1982), which had a positive boost on the country's tourism sector (Gerede, 2010).

The biggest portion of Turkey's proceeds from tourism comes from travel related establishments along the Aegean and the Mediterranean Sea and the city of Istanbul. The dominant share of activity also relies on sun-and-sea approach, though, when compared to Croatia, the travel offer of Turkey is more diversified (conference and golf tourism, health and thermal tourism, winter sports).

\section{SUPPLY SIDE TOURISM INDICATORS}

\subsection{Tourist Accommodation Establishments}

Table 1 indicates that Croatia had altogether 759 (two to five-star rated) hotels and 330 similar accommodation facilities in 2019. Looking just at the hotels, dominant share pertains to four star-hotels (44.9\%) and three-star hotels (42.6\%), while five-star and two-star hotels participate both with around $6,2 \%$ share in total. Croatia also has a strong supply of holiday and other shortstay accommodation (111,820 units in 2019), of which $92.8 \%$ is owned by households. Croatia also has at disposal a significant number of camping grounds (notably along the Adriatic Sea littoral) and 322 hostels (spread along the coast but also mainland Croatia).

Looking dynamically (comparing 2019 with the base 2010), the three-star hotel establishment's share is stagnant, while the strong increase in capacity was observed in the segment of four-star (113.1\%) and five-star hotels (88\%). At the same time, a pronounced drop in share of low quality, two-star hotels was recorded (-52.5\%). Big increase in capacity Croatia also recorded in terms of hostels $(544.0 \%)$ and camping grounds $(261.0 \%) .{ }^{4}$ Increased capacity reflects investment in new establishments, as well as expanding and refurbishing the existing ones (which explains the drop in two-star hotels). An increase in tourism physical indicators (see chapter 4) also had an impact on expanding Croatia's tourism accommodation capacity.

$4 \quad$ Due to non-available data for household holiday and short stay accommodation in 2010, static comparison in this segment is not possible. 
Table 1. Number of tourist accommodation establishments in Croatia

\begin{tabular}{|c|c|c|c|c|c|c|c|c|c|c|}
\hline & 2010 & 2011 & 2012 & 2013 & 2014 & 2015 & 2016 & 2017 & 2018 & 2019 \\
\hline Hotels and similar accommodation & 841 & 857 & 878 & 897 & 909 & 938 & 1,011 & 1,037 & 1,065 & 1,089 \\
\hline - o/w. Two-star hotels & 101 & 96 & 91 & 7 & 79 & 76 & 72 & 69 & 57 & 48 \\
\hline - o/w. Three-star hotels & 314 & 321 & 320 & 328 & 317 & 316 & 316 & 313 & 322 & 323 \\
\hline - o/w. Four-star hotels & 160 & 172 & 190 & 206 & 227 & 245 & 273 & 300 & 322 & 341 \\
\hline - o/w. Five-star hotels & 25 & 29 & 30 & 31 & 34 & 38 & 38 & 42 & 42 & 47 \\
\hline - o/w. Other ${ }^{1)}$ & 241 & 239 & 247 & 325 & 252 & 263 & 312 & 313 & 322 & 330 \\
\hline Holidav and other short-stav accommodation ${ }^{2 / 3)}$ & 1,040 & 1,089 & 56,418 & 60,585 & 66,244 & 71,894 & 81,569 & 96,578 & 106,326 & 111,820 \\
\hline $\begin{array}{l}\text { - o/w. Households } \\
\text { - o/w. Hostels }\end{array}$ & & & & & & & & 89,446 & 98,621 & 103,727 \\
\hline - o/w. Hostels & 50 & 56 & 81 & 126 & 168 & 201 & 283 & 313 & 332 & 322 \\
\hline $\begin{array}{l}\text { Camping grounds, recreational vehicle parks and } \\
\text { trailer parks }\end{array}$ & 236 & 243 & 512 & 544 & 571 & 607 & 653 & 726 & 821 & 852 \\
\hline Total $^{3)}$ & 2,117 & 2,189 & 57,808 & 62,026 & 67,724 & 73,439 & 83,233 & 98,341 & 108,212 & 113,761 \\
\hline
\end{tabular}

1) heritage hotels, all-suite hotels, diffuse hotels, integral hotels, spa-hotels, special standard hotels, resorts, tourist apartments, boarding houses, spa boarding houses and guest houses

2) rooms, apartments, studio-type suits, summer houses, hostels, spas, overnight accommodation, vacation establishments for children, inns, mountain and hunting lodges, pupils and students home

3) households' accommodation included after 2011

\section{Source: Croatian Bureau of Statistics}

Foreign tourists travelling to Turkey opt predominantly for hotel accommodation, mainly because of the all-inclusive hotel packages offered on the market. Accordingly, Table 2 reveals that in 2019 Turkey had altogether 2950 (two to five-star rated) hotels, of which the highest share pertains to three-star hotels (36.1\%), followed by four-star (28.1\%) and five-star hotels $(22.7 \%)$. The smallest share of hotels pertains to two-star hotels (13.1\%). Turkey, when compared to Croatia, has almost 2,200 more hotel establishments, but with a marginal offer in terms of camping grounds and household owned holiday, and other short-stay accommodation.

Looking dynamically (comparing 2019 with the base 2010) the biggest increase in capacity was observed in the five-star hotel segment (109.7\%), followed by three-star hotels $(66.1 \%)$ and four-star hotels $(58.5 \%)$. As in the case of Croatia, the decline in numbers was recorded in low quality segment (number of two-star hotels declined by 174 units or 31.0\%). Vast domestic and foreign investments also played a crucial role in expanding the country's tourism capacity, thus emphasizing the importance of tourism for Turkey's overall real activity.

Table 2. Number of tourist accommodation establishments in Turkey

\begin{tabular}{|c|c|c|c|c|c|c|c|c|c|c|}
\hline & 2010 & 2011 & 2012 & 2013 & 2014 & 2015 & 2016 & 2017 & 2018 & 2019 \\
\hline Hotels and similar accommodation & 2,296 & 2,409 & 2,490 & 2,582 & 2,687 & 2,830 & 3,087 & 3,202 & 3,327 & 3,397 \\
\hline - olw: Two-star hotels & 561 & 532 & 484 & 453 & 414 & 400 & 405 & 407 & 401 & 387 \\
\hline - olw: Three-star hotels & 641 & 691 & 728 & 773 & 823 & 877 & 960 & 1,008 & 1,045 & 1,065 \\
\hline - dw: Four-star hotels & 523 & 554 & 596 & 624 & 657 & 700 & 751 & 781 & 810 & 829 \\
\hline - olw: Five-star hotels & 319 & 366 & 398 & 442 & 485 & 523 & 570 & 595 & 633 & 669 \\
\hline - dw: Other ${ }^{1)}$ & 252 & 266 & 284 & 290 & 308 & 330 & 401 & 411 & 438 & 447 \\
\hline Camping grounds & 4 & 4 & 5 & 5 & 6 & 6 & 7 & 7 & 7 & 7 \\
\hline Other ${ }^{2)}$ & 347 & 370 & 375 & 395 & 438 & 473 & 547 & 562 & 591 & $\overline{634}$ \\
\hline Total & 2,647 & 2,783 & 2,870 & 2,982 & 3,131 & 3,309 & 3,641 & 3,771 & 3,925 & 4,038 \\
\hline
\end{tabular}

1) one star hotels, motels, all-suite hotels, boutique hotels, thermal hotels, thermal all-suite hotels

2) holiday villages, thermal holiday villages, inns, golf facilities with accommodation, tourism complex, mountain house, boarding house, village house, hostels, B type holiday site and private establishments

Source: Turkish Ministry of Culture and Tourism

When it comes to the number of beds available, Table 3 reveals that in (two to five-star rated) hotels Croatia had 127,987 beds available in 2019. As in the case of the number of hotel units, the biggest share of beds pertains to four-star hotels ( $49.6 \%$ with the average number of beds in such hotel amounting to 186 in 2019), followed by share of beds in three-star hotels $(34.3 \%$ with 
on average 136 beds per hotel), share of beds in five-star hotels (9.7\% with on average 264 beds per hotel) and, finally, share of beds in two-star hotels $(6.4 \%$ with on average 171 bed per hotel $) .{ }^{5}$

The total number of beds available in household owned holiday and short-stay accommodation in Croatia equalled 674,428 beds in 2019. These are micro accommodation units with on average only 7 beds. In the same year, hostels provided 17,700 beds or on average 55 beds per unit, and camping grounds 277,214 beds or on average 325 beds (camping spaces/lots per person).

Table 3. Number of bed places in tourist accommodation establishments offered in Croatia

\begin{tabular}{|c|c|c|c|c|c|c|c|c|c|c|}
\hline & 2010 & 2011 & 2012 & 2013 & 2014 & 2016 & 2016 & 2017 & 2018 & 2019 \\
\hline Hotels and similar accommodation & 151,681 & 154,733 & 156,792 & 161,957 & 161,875 & 164,675 & 167,380 & 166,485 & 169,108 & 171,005 \\
\hline$-o / w$ & 17,463 & 18,638 & 18,244 & 18,667 & 16 & 15,955 & 15,042 & 13,755 & 10,433 & 8,195 \\
\hline$-o / w$ & 55,5 & 55,3 & 55, & 56 & 52 & 52,6 & 47 & 44 & 25 & 43,849 \\
\hline$-o / W$ & 39,085 & 41,29 & 43,688 & 47,537 & 52,4 & 55,2 & 59,395 & 62 & 63,345 & 63,518 \\
\hline$-o / w$ & 9,209 & 10,334 & 10,461 & 10,544 & 11,100 & 11,939 & 12,014 & 13,024 & 12,244 & 12,425 \\
\hline$-o / w: 0$ & 30,365 & 29,073 & 29,323 & 28,378 & 28,827 & 28,873 & 33,055 & 33,675 & 37,061 & 43,018 \\
\hline Holidav and other & & & 88 & 0,857 & 496,276 & 529,286 & 569,436 & 42 & 684,160 & 709,651 \\
\hline$-o / w$ & 393,505 & 414,675 & 366,766 & 374,881 & 414,416 & 490,518 & 538,280 & 604,813 & 650,437 & 674,428 \\
\hline - o/w. Hostels & 5,790 & 5,996 & 6,973 & 8,922 & 10,546 & 12,163 & 15,758 & 16,742 & 18,139 & 17,700 \\
\hline $\begin{array}{l}\text { Camping grounds, recreational vehicle parks and } \\
\text { trailer parks }\end{array}$ & 38 & 21 & 78 & 244,296 & 76 & 652 & 250,456 & 256,965 & 262,391 & 277,2 \\
\hline Total $^{3)}$ & 439,613 & 437,758 & 798,928 & 867,110 & 893,827 & 938,613 & 87,272 & 69,992 & 115,669 & $1,167,870$ \\
\hline
\end{tabular}

1) heritage hotels, all-suite hotels, diffuse hotels, integral hotels, spa-hotels, special standard hotels, resorts, tourist apartments, boarding houses, spa boarding houses and guest houses

2) rooms, apartments, studio-type suits, summer houses, hostels, spas, overnight accommodation, vacation establishments for children, inns, mountain and hunting lodges, pupils and students home

3) households' accommodation included after 2011

Source: Croatian Bureau of Statistics

Table 4 reveals that in (two to five-star rated) hotels Turkey had 834,757 beds available in 2019, or 6.5 times bigger amount than Croatia. The biggest share of beds in Turkey pertains to fivestar hotels (54.6\% with the average number of beds in such hotel amounting to 682 in 2019), followed by share of beds in four-star hotels ( $28.0 \%$ with on average 282 beds per hotel), share of beds in three-star hotels (14.3\% with on average 112 beds per hotel) and, finally, share of twostar hotels $\left(3.1 \%\right.$ with on average 68 beds per hotel) ${ }^{6}$

Table 4. Number of bed places in tourist accommodation establishments offered in Turkey

\begin{tabular}{|c|c|c|c|c|c|c|c|c|c|c|}
\hline & 2010 & 2011 & 2012 & 2013 & 2014 & 2015 & 2016 & 2017 & 2018 & 2019 \\
\hline Hotels and similar accommodation & 549,735 & 585,684 & 622,548 & 662,820 & 711,990 & 751,847 & 799,798 & 836,107 & 873,355 & 894,309 \\
\hline - o/w: Two-star hotels & 43,711 & 40,734 & 36,673 & 33,943 & 30,801 & 29,494 & 28,602 & 28,471 & 27,682 & 26,268 \\
\hline - o/w: Three-star hotels & 86,316 & 92,363 & 94,134 & 97,579 & 106,437 & 107,236 & 108,586 & 115,919 & 118,996 & 119,070 \\
\hline - o/w: Four-star hotels & 168,812 & 167,359 & 179,585 & 189,400 & 200,662 & 214,504 & 220,440 & 228,901 & 232,463 & 233,410 \\
\hline - o/w: Five-star hotels & 220,474 & 251,103 & 272,777 & 301,406 & 329,725 & 354,641 & 390,576 & 409,064 & 436,075 & 456,009 \\
\hline - o/w: Other ${ }^{1)}$ & 30,422 & 34,125 & 39,379 & 40,492 & 44,365 & 45,972 & 51,594 & 53,752 & 58,139 & 59,552 \\
\hline Camping grounds & 587 & 660 & 750 & 705 & 2,005 & 2,005 & 2,425 & 2,425 & 2,425 & 2,425 \\
\hline Other ${ }^{2}$ & 79,143 & 82,485 & 82,721 & 85,774 & 93,321 & 96,237 & 97,658 & 96,754 & 98,794 & 95,607 \\
\hline Total & 629,465 & 668,829 & 706,019 & 749,299 & 807,316 & 850,089 & 899,881 & 935,286 & 974,574 & 992,341 \\
\hline
\end{tabular}

1) one-star hotels, motels, all-suite hotels, boutique hotels, thermal hotels, thermal all-suite hotels

2) holiday villages, thermal holiday villages, inns, golf facilities with accommodation, tourism complex, mountain house, boarding house, village house, hostels, B type holiday site and private establishments

Source: Turkish Ministry of Culture and Tourism

\footnotetext{
$5 \quad$ The shares do not add to $100 \%$ since other category includes, among other accommodation facilities, also one-star hotels.

6 The shares do not add to $100 \%$ since other category includes, among other accommodation facilities, also one-star hotels.
} 
At the same year, other accommodation facilities in Turkey (holiday villages, thermal holiday villages, inns, golf facilities with accommodation, tourism complex, mountain house, boarding house, village house, hostels, B type holiday site and private establishments) offered in 2019 95,607 beds or, on average, 151 bed per such facility. The number of beds offered by Turkish camping grounds in the same year amounted to 2,425 or, on average, 346 beds (camping spaces/ lots per person).

Table 5 and Table 6 reveal other selected tourism facilities in Croatia and Turkey that pertain to marinas, airports and golf facilities. They reveal that nautical tourism is much more important for Croatia compared to Turkey, as seen in the number of available marinas in 2019 (78 in Croatia versus 41 in Turkey). On the other hand, due to its geographical location and smaller share of drive-in foreign guests, Turkey has a significantly bigger share of airport facilities (56 compared to only 7 in Croatia). Golf tourism is also much more developed in Turkey than it is in Croatia (14 and 5, respectively), though the number of terrains has been on the decline in Turkey since 2010 due to high maintenance costs.

Table 5. Number of other selected tourism facilities in Croatia

\begin{tabular}{lrrrrrrrrrr}
\hline & 2010 & 2011 & 2012 & $\mathbf{2 0 1 3}$ & $\mathbf{2 0 1 4}$ & $\mathbf{2 0 1 5}$ & $\mathbf{2 0 1 6}$ & $\mathbf{2 0 1 7}$ & $\mathbf{2 0 1 8}$ & $\mathbf{2 0 1 9}$ \\
\hline Marinas $^{1)}$ & & 54 & 53 & 53 & 56 & 57 & 58 & 57 & 58 & 78 \\
Airports $^{2)}$ & 9 & 9 & 9 & 9 & 9 & 9 & 9 & 9 & 9 & 9 \\
Golf facilities $^{3)}$ & & & & & & & & & 5 & 5 \\
\hline
\end{tabular}

1) Tourism in numbers 2011-2019

2) Data relate to the airports in Zagreb, Split, Dubrovnik, Pula, Rijeka, Zadar, Osijek, Brač and the air landing place in Mali Lošinj.

3) Data relate to the golf courses: Riverside Golf Zagreb, Golf igralište Adriatic, Brijuni Old Golf Course, Golf igralište Sv. Martin Međimurje and Golf centar Novi Dvori.

Sources: Croatian National Tourist Board, Croatian Bureau of Statistics, Croatian Golf Association

Table 6. Number of other selected tourism facilities in Turkey

\begin{tabular}{lrrrrrrrrrr}
\hline & $\mathbf{2 0 1 0}$ & $\mathbf{2 0 1 1}$ & $\mathbf{2 0 1 2}$ & $\mathbf{2 0 1 3}$ & $\mathbf{2 0 1 4}$ & $\mathbf{2 0 1 5}$ & $\mathbf{2 0 1 6}$ & $\mathbf{2 0 1 7}$ & $\mathbf{2 0 1 8}$ & $\mathbf{2 0 1 9}$ \\
\hline Marinas $^{\text {1) }}$ & & 42 & 42 & 42 & 42 & 43 & 44 & 41 & 43 & 41 \\
- o/w. Yacht ports & & 17 & 17 & 17 & 17 & 23 & 26 & 26 & 27 & 28 \\
Airports $^{2)}$ & 46 & 47 & 49 & 52 & 53 & 55 & 55 & 55 & 56 & 56 \\
Golf facilities $^{1)}$ & 22 & 21 & 19 & 15 & 12 & 15 & 15 & 15 & 15 & 14 \\
\hline
\end{tabular}

1) Maritime Sector Reports (2011-2015)

2) Included airports supervised by the State Airports Authority of Turkey.

Sources: Turkey's Ministry of Culture and Tourism, Turkish Chamber of Shipping, State Airports Authority of Turkey

\section{DEMAND SIDE TOURISM INDICATORS}

This section of the paper focuses on the comparison of physical indicators in tourism for Croatia and Turkey, gathered from official sources.

\subsection{Arrivals and Nights Spent by Foreign Tourists}

Figure 1 and Figure 2 represent the yearly changes in foreign tourist arrivals and foreign tourist nights spent at tourist accommodation facilities in Croatia and Turkey in the past two decades (from the year 2000 to the year 2019). 


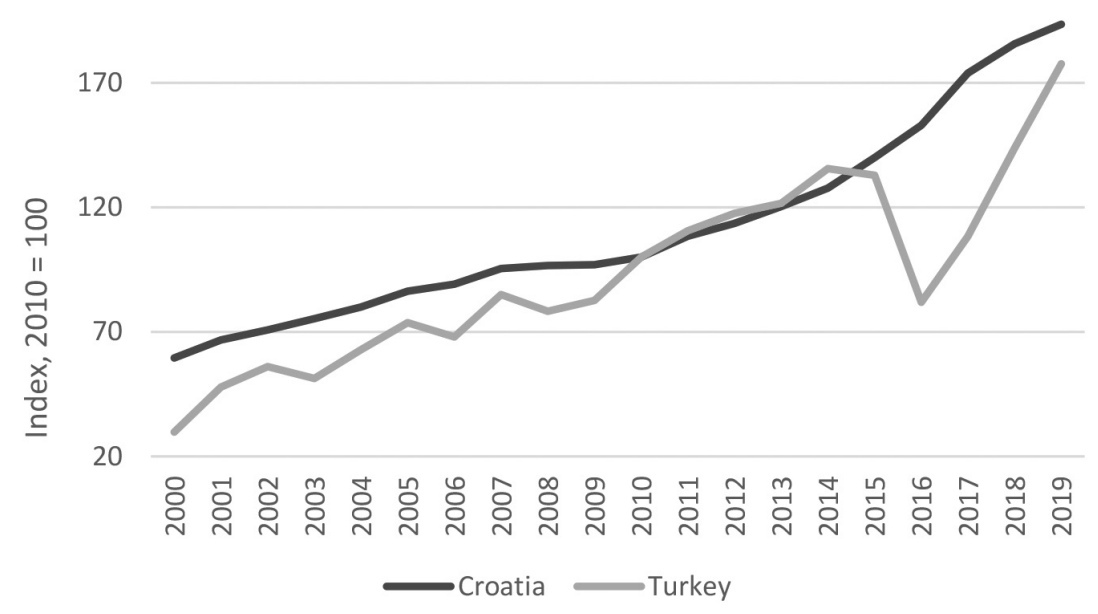

Figure 1. Foreign tourist arrivals (yearly changes, 2000-2019)

Sources: Croatian Bureau of Statistics, Turkish Ministry of Culture and Tourism

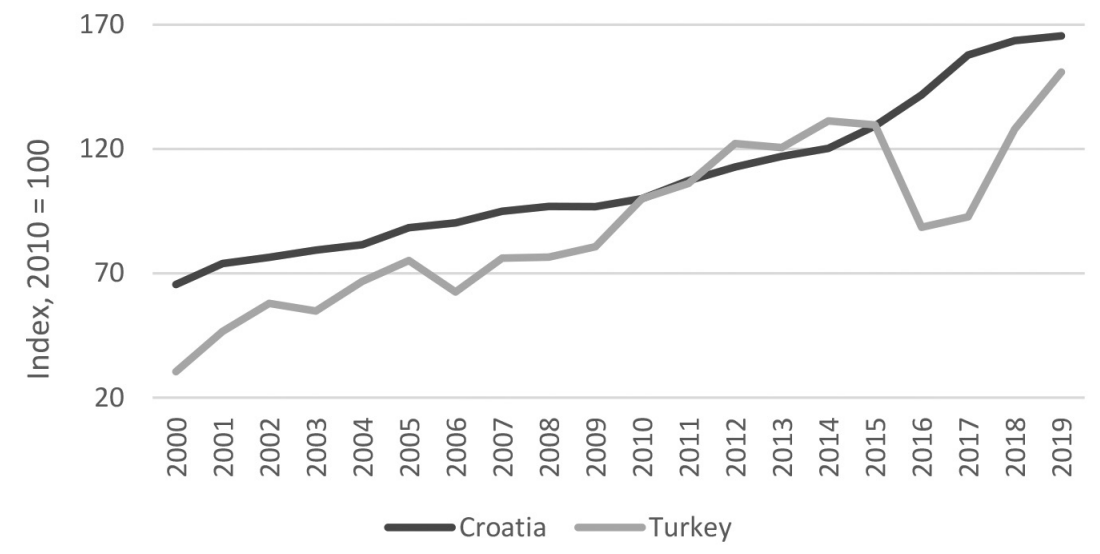

Figure 2. Foreign tourist nights spent (yearly changes, 2000-2019)

Sources: Croatian Bureau of Statistics, Turkish Ministry of Culture and Tourism

Croatia, in the period before the great financial crisis, saw a sustained increase in both foreign tourist arrivals and nights spent (in the period from 2000 to, including 2008, the average yearly growth rate in number of arrivals amounted to $5.9 \%$, and number of nights spent to $4.8 \%$ ). In 2009 and the aftermath of the global financial crisis, a slowdown in physical indicators has been recorded, which can be attributed to high economic uncertainty and, in some emitting countries, decline in disposable incomes. After Croatia entered European Union, a significant rebound in physical indicator growth rates was recorded (in the period from 2016 till 2019 the average annual growth rate of number of arrivals amounted to $8.4 \%$, and nights spent to $6.4 \%$ ) that was propped up by further infrastructural developments by both private and corporate (domestic and international) investors.

In the period before the crises Turkey recorded a similar, sustained increase in physical indicators in tourism, though its dynamics were somewhat more volatile compared to Croatia (the average yearly increase in foreign tourist arrivals from 2000 to 2008 amounted to $7.8 \%$, and nights spent 9.6\%). In years following the crises, the number of foreign tourists arriving in Turkey continued to increase and they spent more nights in Turkey as well. The sharp decline in the tourism industry occurred in 2016 caused by terrorist attacks that hit big cities in 2015 and 2016. Since 2017, and especially after the normalization of Turkey-Russia relations, foreign tourist arrivals and nights spent started to increase again. The significant depreciation of the 
Turkish lira in 2018 and ensuing increase in purchasing power of foreign tourists (Genç, 2018) also helped in boosting the physical indicators at the very end of analysed interval (in the period from 2017 till 2019 the average annual growth rate of number of arrivals in Turkey amounted to $15 \%$, and nights spent to $12.6 \%$ ).

\subsection{Intra-Year Distribution of Arrivals and Nights Spent by Foreign Tourists}

As Figure 3 and Figure 4 show, climate factors play a key role in intra-year distribution of physical indicators, with both countries' peak of the tourism season coinciding with warm and dry weather. The mentioned figures also show that for Croatia seasonality is more pronounced, July and August being the months with high and concentrated tourism business. On the other hand, Turkey's season is wider and encompasses the interval from May to October.

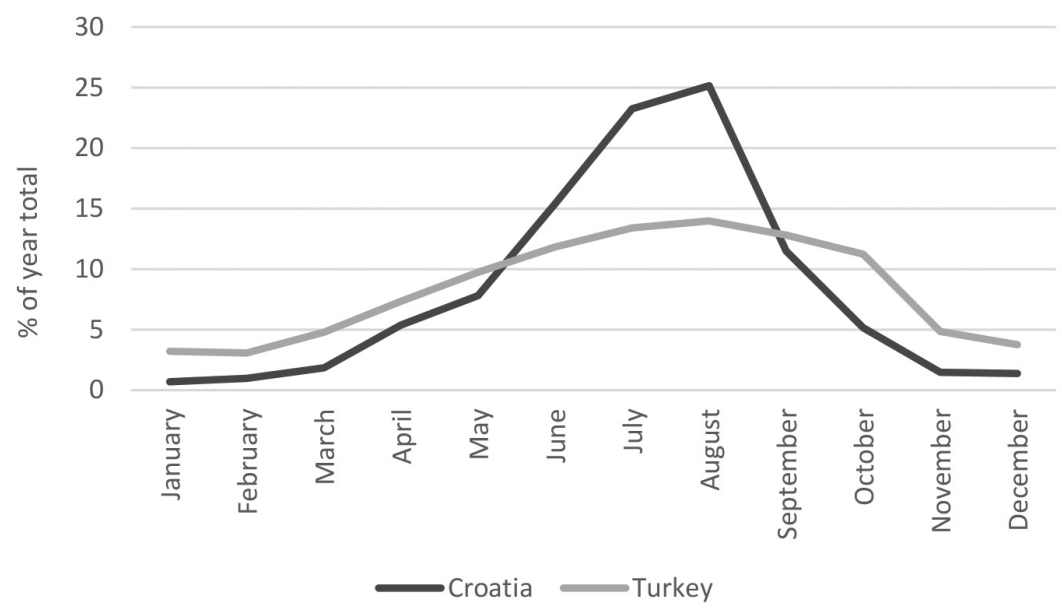

Figure 3. Distribution of foreign tourist arrivals by months (2019)

Sources: Croatian Bureau of Statistics, Turkish Ministry of Culture and Tourism

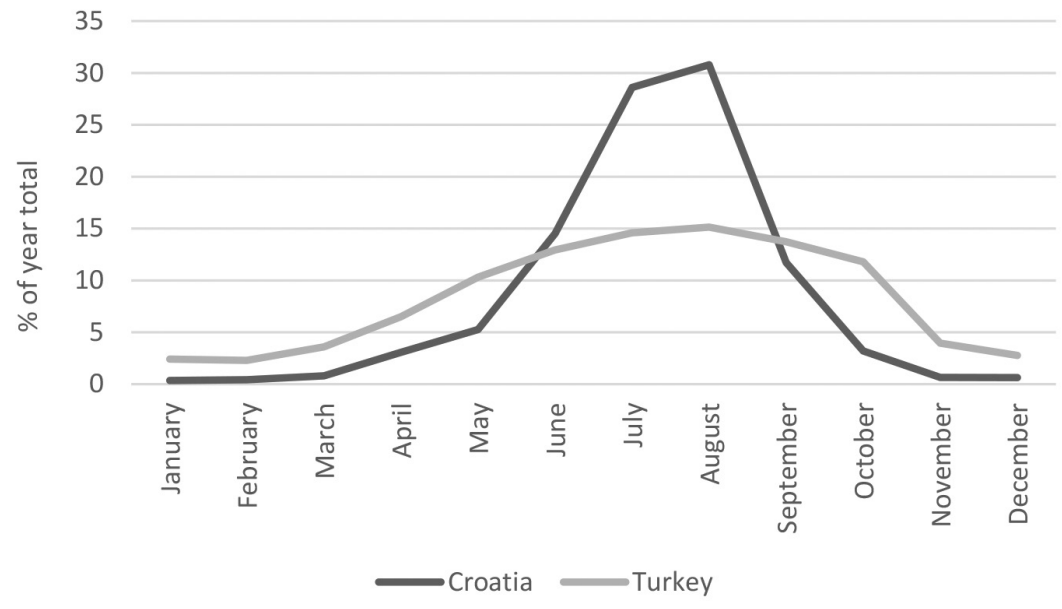

Figure 4. Distribution of foreign tourist nights spent by month (2019)

Sources: Croatian Bureau of Statistics, Turkish Ministry of Culture and Tourism

When it comes to occupancy rates of rooms in hotels and similar accommodation facilities (the data in the Figure 5 refer to year 2018), for Croatia they range between 20\% and 50\% in low season (from October to April, with the weakest rate in January), while at the peak of the season (August-September) they surpass 90\%. Occupancy rates in Turkey follow similar seasonal pattern, with somewhat higher shares during autumn and winter months, partly due to 
country's geographic position and climate characteristics, but somewhat lower occupancy rates during spring and summer months. These findings corroborate higher seasonality of Croatian compared to the Turkish tourism sector. However, one should recall that in Turkey hotels and similar accommodation facilities cover more than $85 \%$ of the entire market for tourism related rentals, while in Croatia they account for just one-fifth of total nights spent.

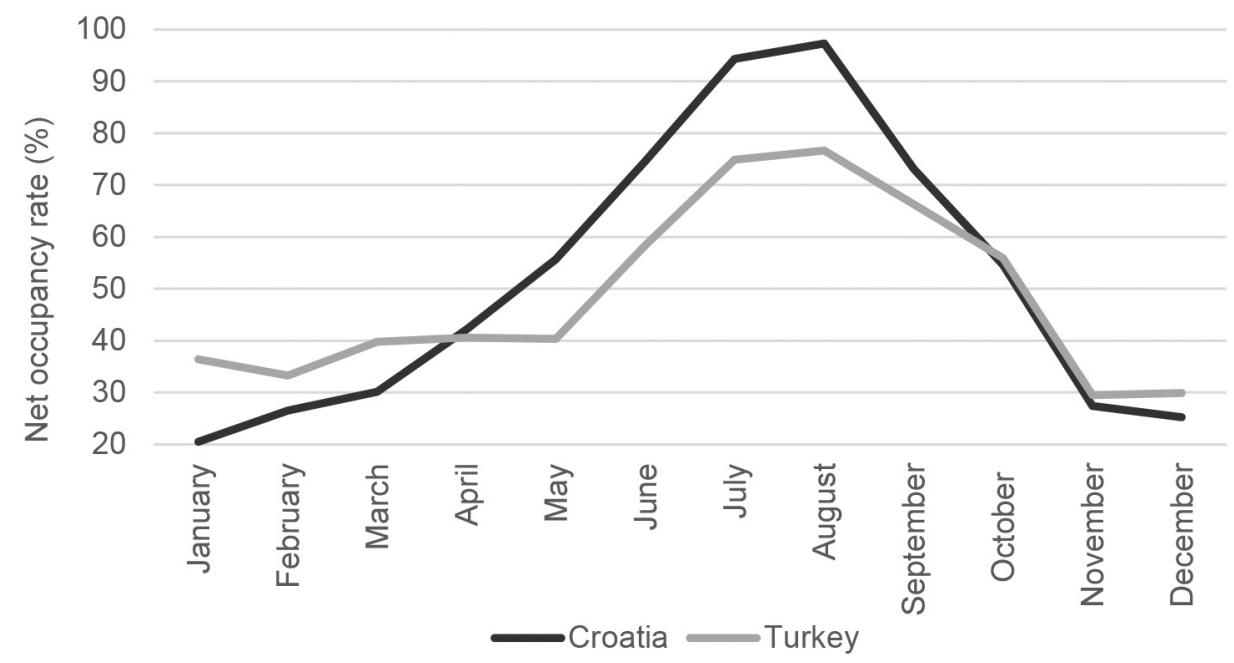

Figure 5. Occupancy rates of hotels and similar accommodation facilities (monthly)

Source: Eurostat

\subsection{Country of Residence Distribution of Foreign Tourists}

Figure 6 and Figure 7 show the distribution of foreign tourist arrivals and nights spent by the country of foreign visitor residence for Croatia. In 2019, German tourists constituted the biggest share of foreign arrivals and nights spent, followed by tourists from Slovenia, Austria, Italy and Poland.

Figure 8 and Figure 9 point to the dominance of Russian and German tourists in the number of arrivals and nights spent in Turkey. In the case of guests from Russia, the fact mirrors the visa exemption regime between two countries and bilateral cooperation in the fields of economy and trade. The number of visitors from Germany is additionally boosted by the fact that a significant number of people of Turkish origin live there and prefer to spend their vacations in Turkey. In 2019, these two countries were followed by guests from the United Kingdom, Poland and China.

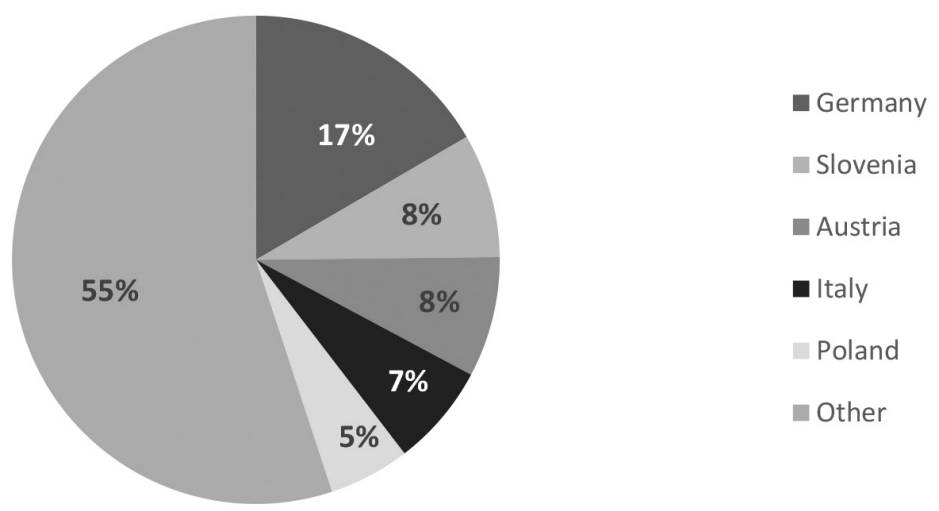

Figure 6. Foreign tourist arrivals to Croatia by country of residence (2019)

Source: Croatian Bureau of Statistics 


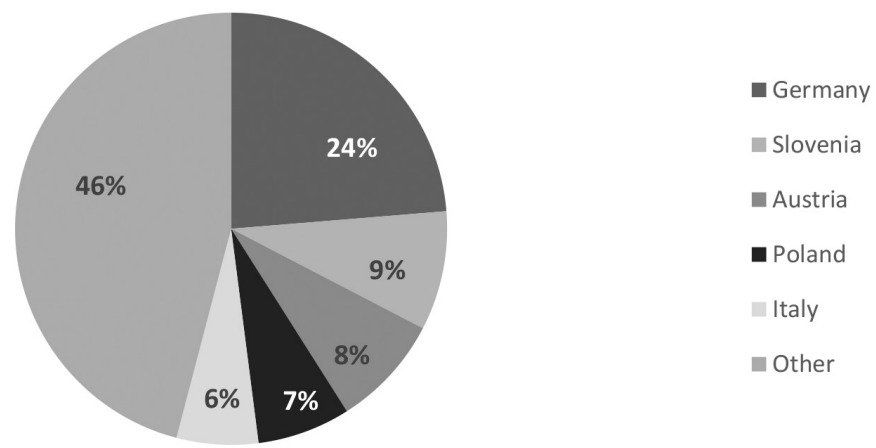

Figure 7. Foreign tourist nights spent in Croatia by country of residence (2019)

Source: Croatian Bureau of Statistics

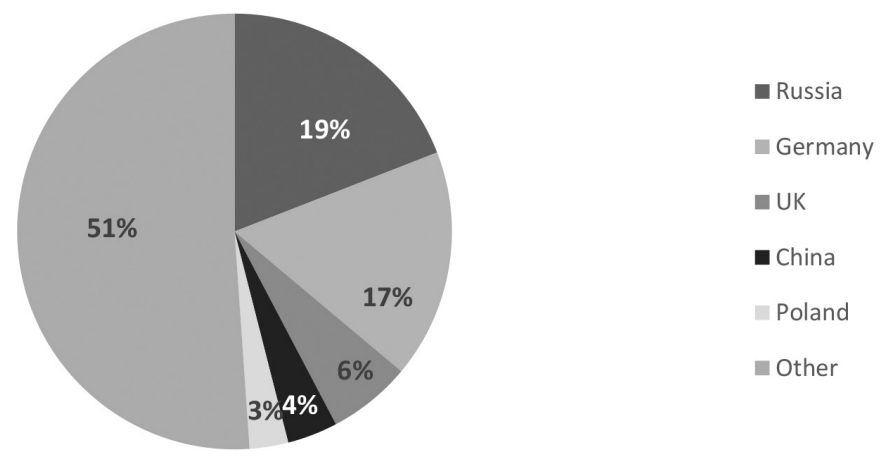

Figure 8. Foreign tourist arrivals to Turkey by country of residence (2019)

Source: Turkish Ministry of Culture and Tourism

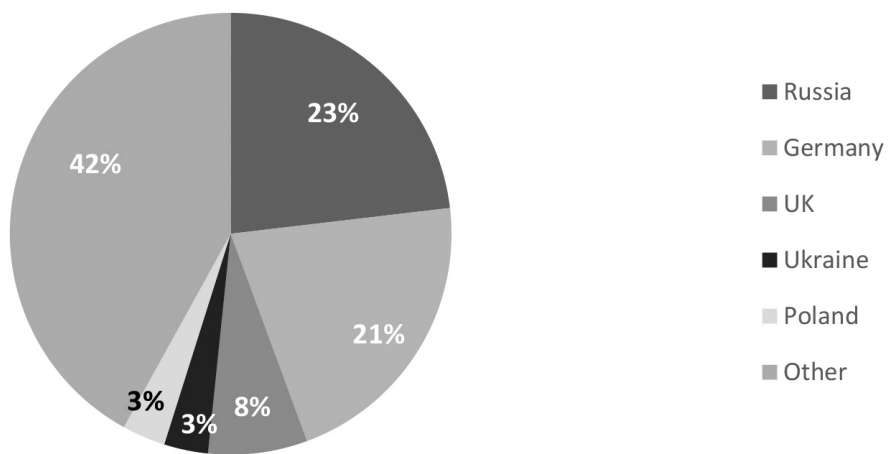

Figure 9. Foreign tourist nights spent in Turkey by country of residence (2019)

Source: Turkish Ministry of Culture and Tourism

\subsection{Means of Transportation Distribution of Foreign Tourists}

Figure 10 and Figure 11 can be used for comparison of Croatia and Turkey in terms of means of transportation of international tourists arriving to respective countries, covering intervals from 2010 to the most recent 2019.

Figure 10, about Croatia, clearly points to the dominance of drive-in guests, followed by increasing air-borne and relatively constant share of ferry-carried passengers. This distribution reflects the highly-developed highway network in Croatia, cruise ship visits and, to less extent, domestic international ferry transport systems. Air-borne tourists arrive in Croatia mostly from the United Kingdom, the United States and South Korea. 


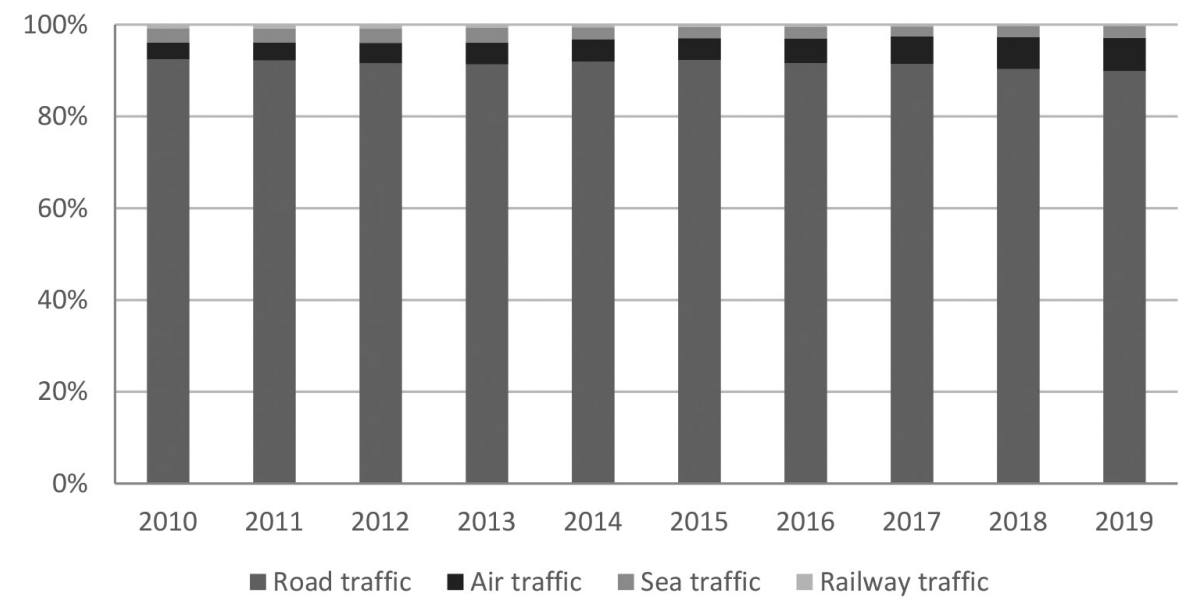

Figure 10. Distribution of cross-border entry of foreign travellers to Croatia (2010-2019)

Source: Croatian Bureau of Statistics

Figure 11, about Turkey, shows that due to its geographical location, but also highly developed and globally strong national air carrier (Turkish Airlines) and many seasonal (low-costs and charter) air connections, most of Turkey's visitors arrive by plane (in last two years the share of this segment slightly surpasses $75 \%$ ). When it comes to this segment, most of the visitors who use plane transportation come from Russia, Germany, the UK and Ukraine. On the second place are road arrivals, followed by sea arrivals of foreign visitors to Turkey.

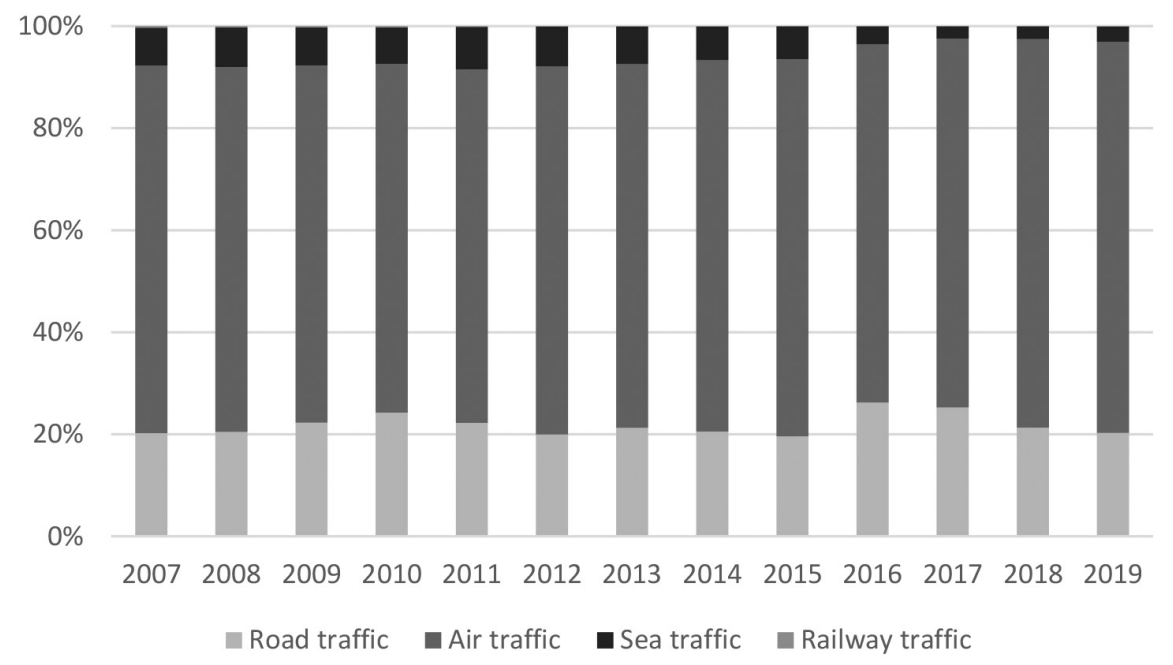

Figure 11. Distribution of cross-border entry of foreign travellers to Turkey (2010-2019)

Source: Turkish Ministry of Culture and Tourism

\subsection{Type of Accommodation Distribution of Foreign Tourists}

Figure 12 and Figure 13 show the distribution of foreign tourist nights spent by type of accommodation in Croatia and Turkey, from 2010 to the last available and comparable 2018.

In Croatia, the majority of tourists prefer to spend their vacation in rooms, apartments, studio-type suites and/or summer houses and other types of accommodation. Some foreign visitors also own property on the coast (mostly from Slovenia). This type of accommodation is followed by the share of camping sites and, in the third place, hotels. 


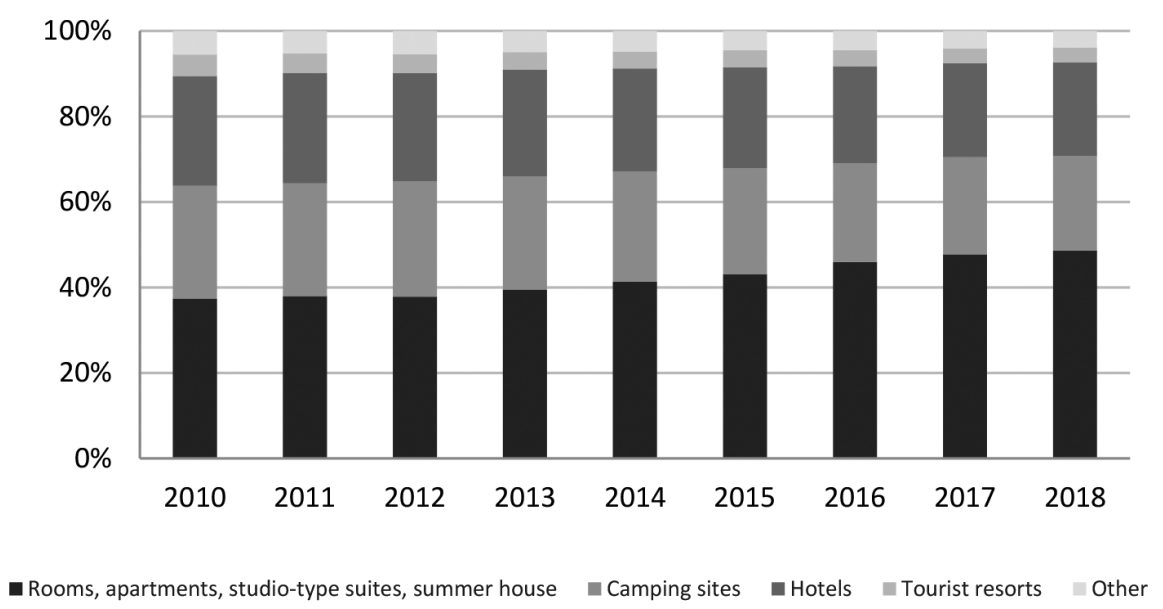

Figure 12. Distribution of foreign tourist nights spent by type of accommodation in Croatia (2010-2018)

Source: Croatian Bureau of Statistics

International visitors travelling to Turkey usually opt for hotel accommodation, with the share of this segment over $80 \%$ and in most recent years rising. While tourist resorts appear only with a marginal share in Croatia's distribution, they show up with a significant share in Turkey's distribution by type of accommodation. Only a small percentage of the international travellers spend their vacations at rooms, apartments, studio-type suites and/or summer houses.

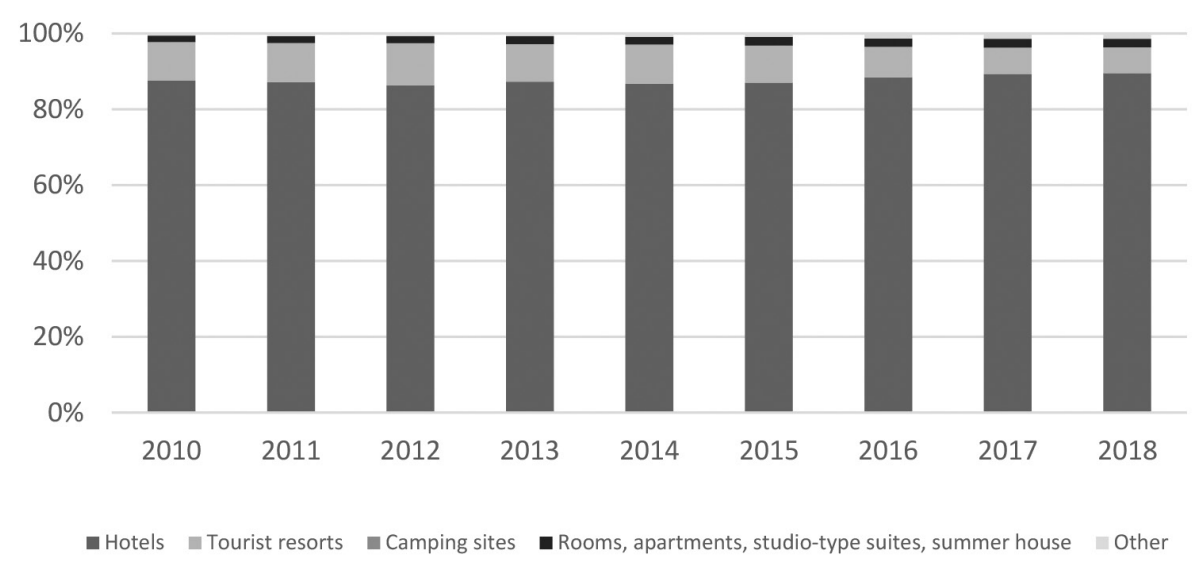

Figure 13. Distribution of foreign tourist nights spent by type of accommodation in Turkey (2010-2018)

Source: Turkish Ministry of Culture and Tourism

Taking into account the fact that the dominant share of foreign tourists in Turkey opt for hotel accommodation, Figure 14 and Figure 15 reveal the star rating distribution of that particular segment. The pie chart pertaining to Turkey (Figure 14) shows that two thirds of foreign tourists stayed at five-star hotels in 2018, followed by a quarter of them who stayed in four-star hotels and only $7 \%$ of them spent their holidays in three-star hotels. Foreign tourists' high demand for five-star or four-star hotels in Turkey can be explained by all-inclusive hotel packages, as well as the fact that they have a competitive price. 


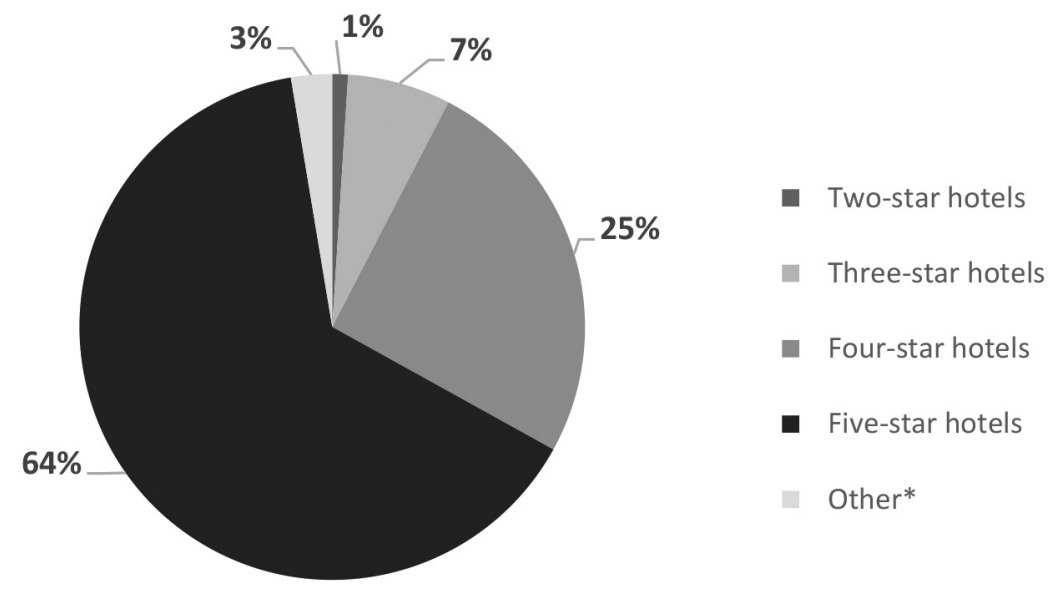

Figure 14. Distribution of foreign tourist nights spent in hotels establishments in Turkey (2018) Source: Turkish Ministry of Culture and Tourism

In the case of Croatia, half of the foreign visitors who opt to stay in hotels do so in four-star rated establishments, and $29 \%$ of them in three-star rated hotels. Only one-tenth of foreign visitors stay in Croatia's five-star rated hotels. Such distribution mirrors the supply of hotel establishments but also their price level, as well as the fact that the share of all-inclusive packages plays much smaller importance in Croatia's tourist offer.

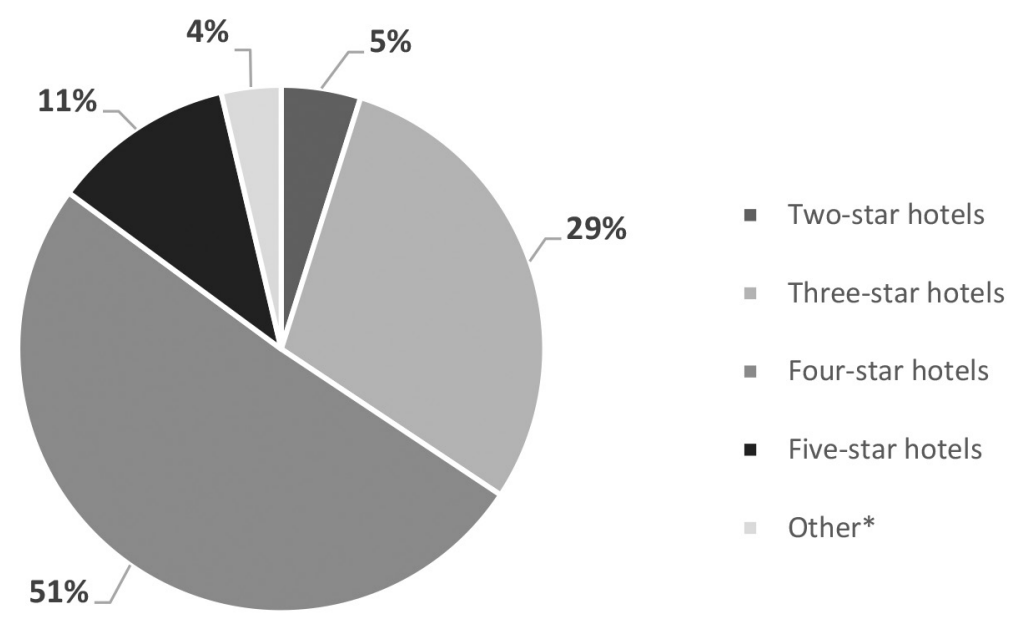

Figure 15. Distribution of foreign tourist nights spent in hotel establishments in Croatia (2018)

Source: Croatian Bureau of Statistics

\subsection{Tourism Financial Indicators}

Figure 16 and Figure 17 show the travel revenues of Croatia and Turkey in absolute terms (billion EUR) and as the percent of gross domestic product. Travel revenues mirror dynamics of physical indicators and average personal consumption per foreign visitor dynamics. In the period before the global financial crisis tourism revenues in Croatia, on average, amounted to around 4,3 billion EUR or 13\% of its GDP. During 2009 and 2010, the mentioned share slightly decreased and since 2011 has been continuously increasing. Accordingly, in the past four years, the relative financial proceeds from travel increased from 16\% of GDP to close to $20 \%$ of Croatia's GDP.

Though Turkey also relies on tourism revenues as a source of foreign currency and for improving its current account balance of payments position (Cihangir, Erkan and Harbalığlu, 2014), 
Figure 16 reveals that Turkey is less dependent on tourism when compared to Croatia. In the entire analysed period its travel revenues on average amounted to 16,7 billion EUR or around $3 \%$ of GDP with an increasing trend observed in the last three years.

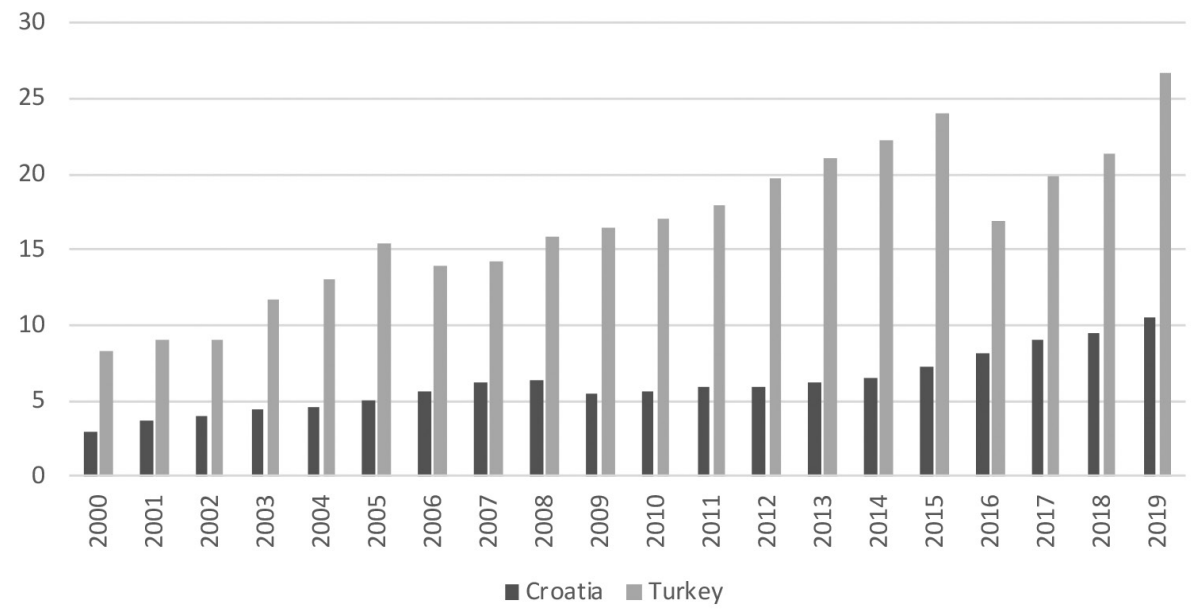

Figure 16. Travel revenues (in billion EUR, 2000-2019)

Sources: Central Bank of Turkey, Croatian National Bank

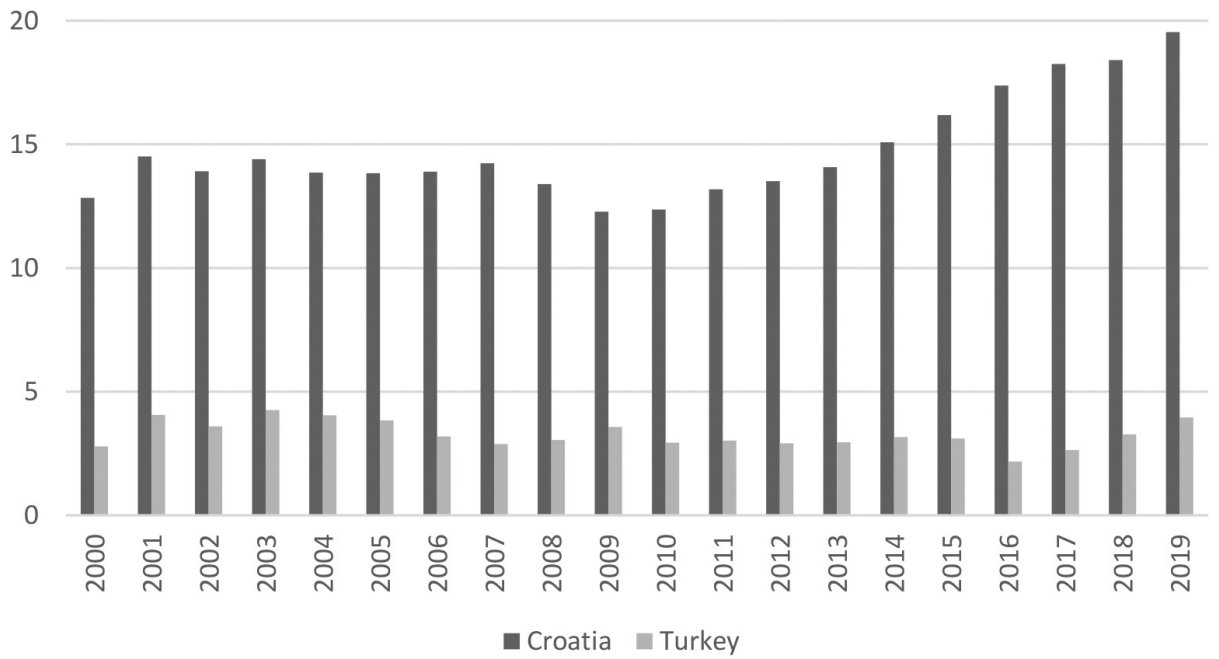

Figure 17. Travel revenues (in percent of GDP, 2000-2019)

Sources: Central Bank of Turkey, Croatian National Bank

\section{TOURISM CONTRIBUTION TO REAL AND LABOUR MARKET DYNAMICS}

The tourism sector has an important potential to increase gross domestic product and gross value added of countries, their employment opportunities, thus contributing to balance of payments and propping up the foreign currency and capital inflows (Bozgeyik and Yoloğlu, 2015).

\subsection{Tourism Contribution to Gross Domestic Product}

The tourism sector contribution to gross domestic product (GDP) formation can be divided into two categories: direct and indirect contribution. The direct contribution represents GDP generated by industries that deal directly with tourists, including hotels, travel agents, airlines and other passenger transport services, as well as the activities of restaurant and leisure industries that again deal directly with tourists. It is equivalent to total internal travel and tourism 
spending within a country less the purchases made by those industries (including imports). On the other hand, total contribution represents GDP generated directly by the travel and tourism sector plus its indirect and induced impacts. Indirect impacts encompass the other sectors that contribute to the tourism sector through the supply chain.

Taking into consideration two points in time (values for 2010 and 2019), Figure 18 shows that the total contribution of GDP in Croatia is approximately double the amount of Turkey's contribution to GDP (in other words, Turkey's GDP formation is more diversified and more reliant on merchandise exports in comparison to Croatia). In both countries, the total contribution of the tourism sector to GDP formation increased over time, with pronounced direct and indirect contributions (though Turkey has a slightly more pronounced share of direct contribution when compared to Croatia).

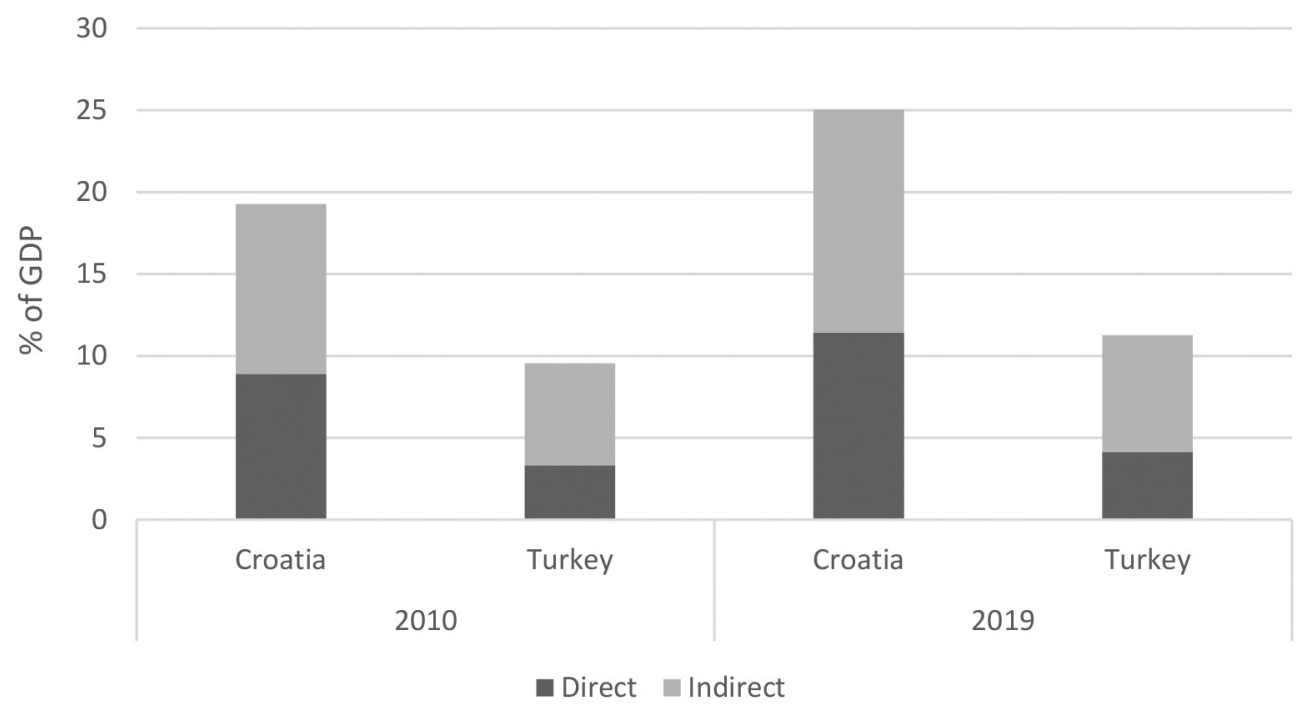

Figure 18. Direct and indirect contribution of tourism to GDP

Sources: World Travel and Tourism Council, Croatian National Bank, Eurostat

\subsection{Tourism Contribution to Gross Value Added}

Though important for both countries, Figure 19 shows that contribution of tourism (measured by accommodation and food service activities) to total gross value added (GVA) is again higher in Croatia than in Turkey, thus confirming Croatia's higher concentration and reliance on tourism. Before the global financial crisis, the direct contribution of tourism services in Croatia amounted to around $4 \%$ of GVA, with an increasing trend after Croatia became the EU Member State (since 2016 the direct contribution of tourism related services surpassed $6 \%$ of GVA). In the entire analysed period share of tourism services in Turkey's total GVA saw smaller changes and fluctuated between $2.6 \%$ and $3.7 \%$, with a rising trend after the global financial crises, followed by a decline in 2016 and 2017, mostly due to the shock tourism sector was exposed to.

Figure 20 reveals that gross value added per employee in accommodation and food service activities in the entire observed period in Croatia is significantly higher than in Turkey, which indicates higher labour productivity in the tourism sector in Croatia compared to Turkey. 


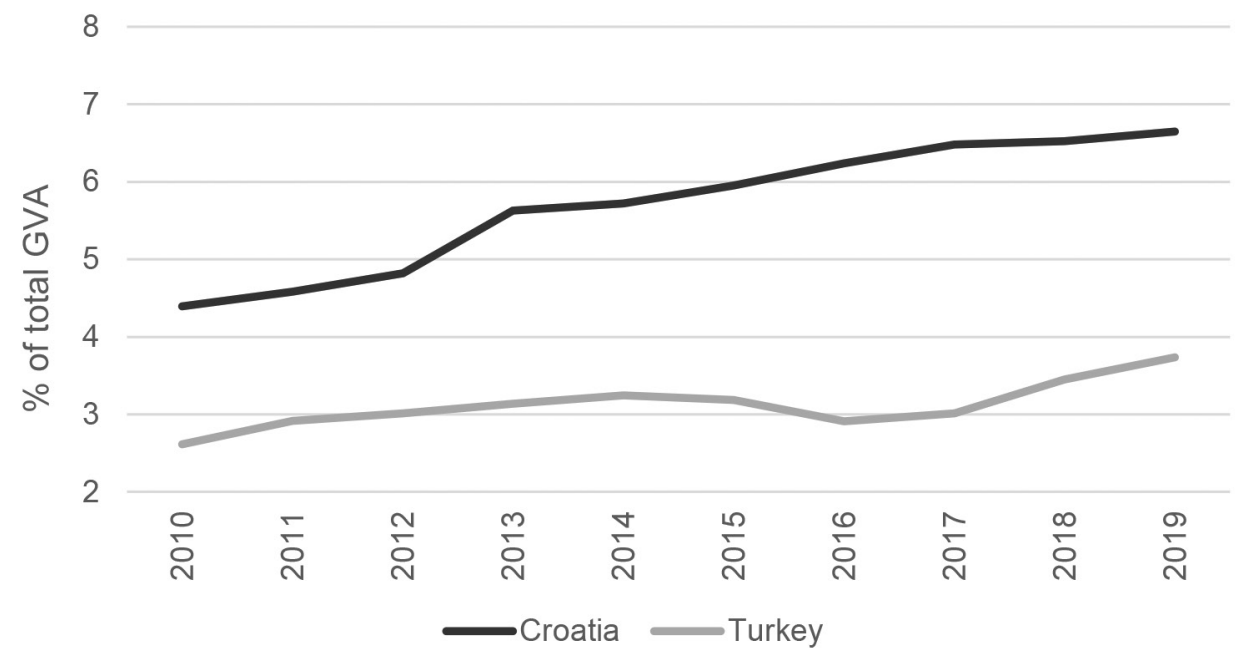

Figure 19. Gross value added in accommodation and food service activities

Source: Eurostat

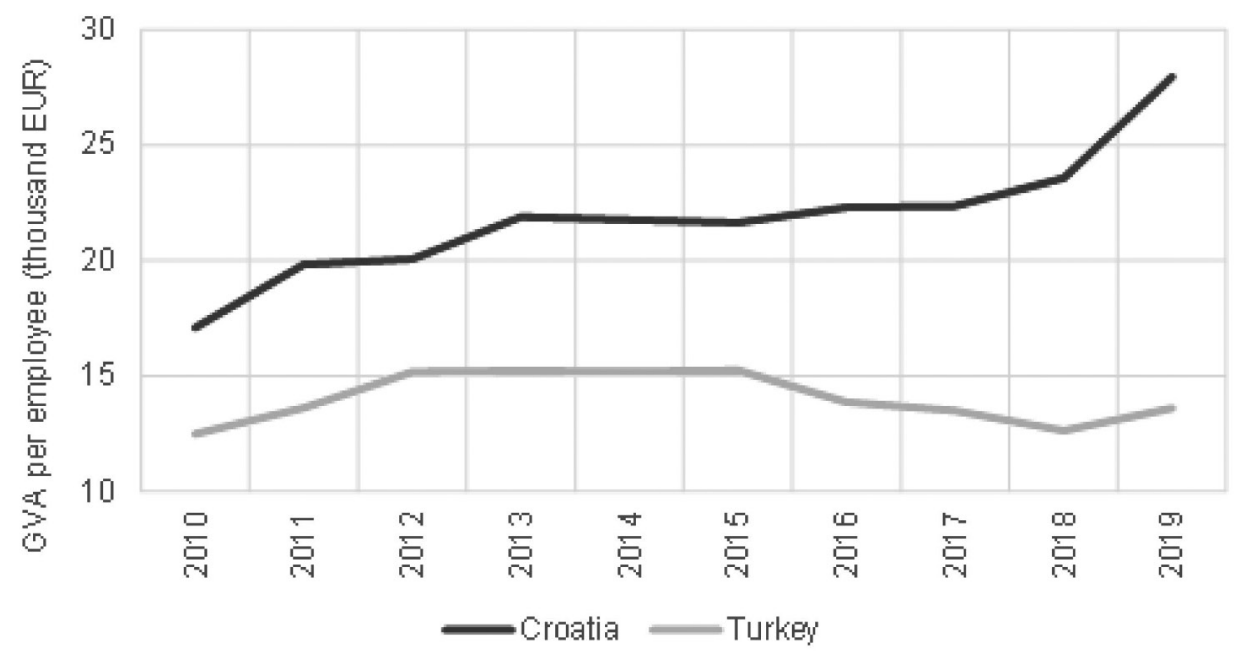

Figure 20. Gross value added per employee in accommodation and food service activities

Source: Eurostat

\subsection{Tourism Contribution to Employment}

The tourism sector offers significant employment opportunities to both developed and developing countries. Figure 21 thus shows the share of the employed person in accommodation and food services in the total number of employed in both analysed countries. Even though Turkey and Croatia differ in terms of tourism's share in the gross domestic product, they are quite similar when compared in terms of the share of the employed person in this segment of activity. The average number of employed in Turkey in this segment amounts to slightly over 5\% of the total number of employed persons, while in Croatia the average for 2008-2019 is only 1 percentage point higher. Since 2014, and reflecting dynamics of physical and financial proceeds in/from tourism, Croatia experienced a sustained increase in the number of employed in this sector. After Croatia joined the EU, the ensuing net emigration of Croats had a negative impact on the possibility to find an adequate workforce in this sector and work permits for foreigners were issued to address this bottleneck (especially seen in 2019). Starting from 2012, the number of employed in accommodation and food service activities has also been increasing in Turkey, with a noticeable surge in 2019. 


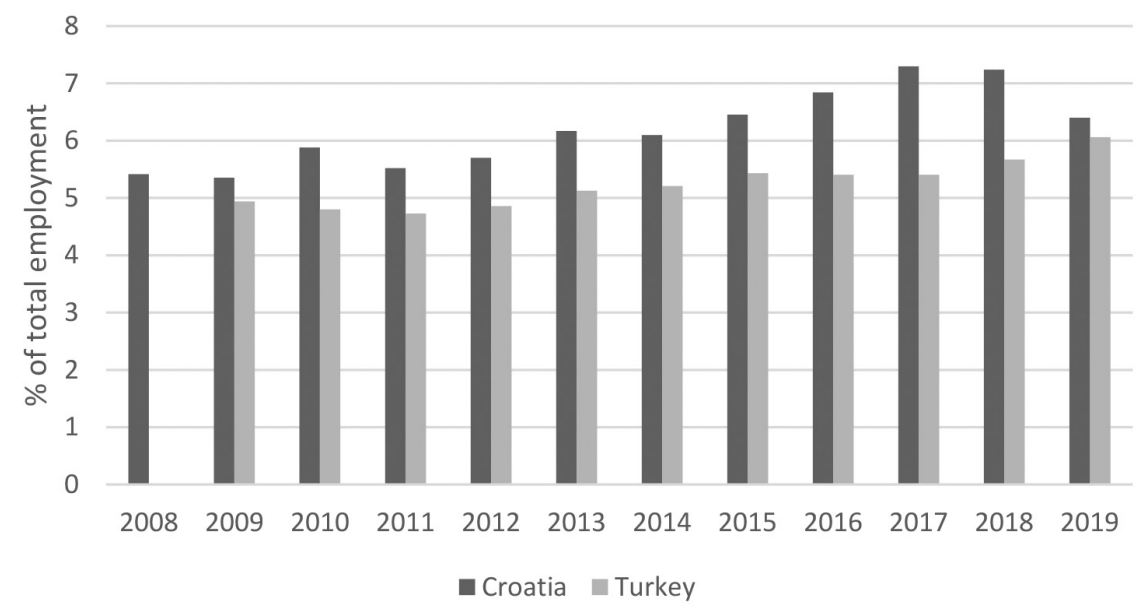

Figure 21. Employment in accommodation and food service activities (2008-2019)

Source: Eurostat

In Figure 22 labour cost index (LCI) was used to show the total hourly cost of labour employed in accommodation and food services. In the interval between 2010 and 2019 pronounced increase characterized LCI for Turkey. Such dynamics were propped up by wage increases, bonuses paid, spending for staff training (especially for new, unskilled and/or semi-skilled employees), inflation developments and, after 2016, strong depreciation of the Turkish lira. In Croatia, the increases in LCI realized since 2010 were offset by the decline recorded in 2016, after which LCI slowly continued to grow. Cumulatively, in the entire period, the LCI in Croatia augmented by less than $20 \%$, while in Turkey the positive cumulative change was significantly higher.

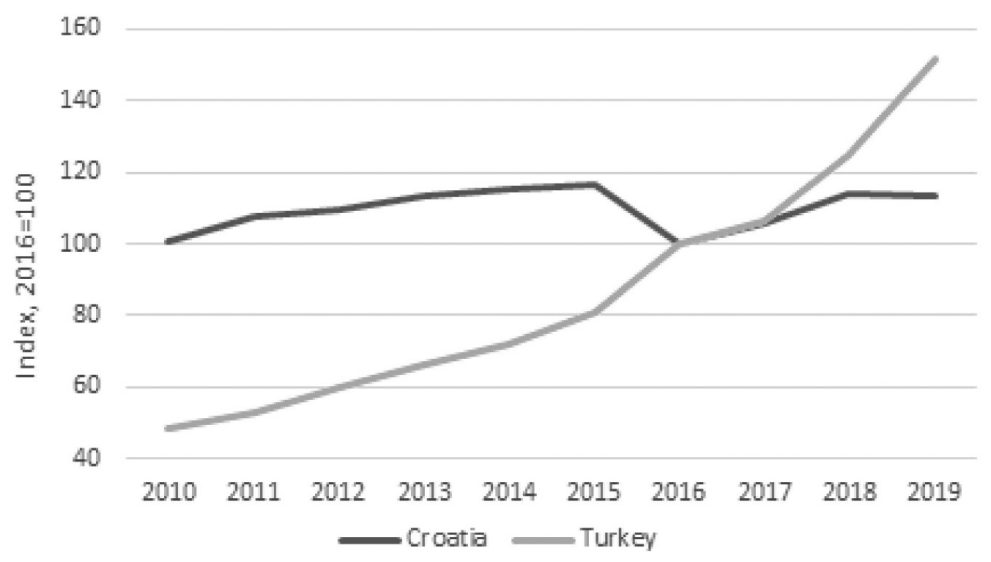

Figure 22. Labour cost index in accommodation and food service activities

Source: Eurostat

\section{COMPETITIVENESS DETERMINANTS}

\subsection{Nominal Exchange Rate}

Figure 23 shows the movements in EUR/HRK (euro versus Croatian kuna) and EUR/TRY (euro versus Turkish lira) nominal (bilateral) exchange rates (between respective countries and Euro Area integration).

Croatia is a small, open and import dependent economy, affected by two-sided euroisation and high level of foreign debt (predominantly denominated in euro). As a result, its central bank 
implements a tightly managed exchange rate regime and intervenes on the foreign exchange market when it deems that movements in exchange rate do not reflect changes in economic fundamentals in a relatively short time interval. As a result, Figure 23 reveals striking fixity of Croatia's nominal exchange rate.

The central bank of Turkey implements a floating exchange regime. Though foreign exchange market supply and demand determine predominantly the EUR/TRY exchange rate, in the event of excessive appreciation or depreciation of the Turkish lira monetary authority takes measures and/or intervenes on the market. Figure 23 reveals that the Turkish lira depreciated significantly concerning euro since 2015 with a combination of factors influencing such dynamics. Since 2012 Turkey recorded balance of payments deficits financed by foreign savings. As a result, Turkey's gross external debt swelled prompting fears that the country might encounter problems in servicing its external obligations. At the same time, some analysts questioned the adequacy of its international reserves and the reference interest rate policy of the central bank.

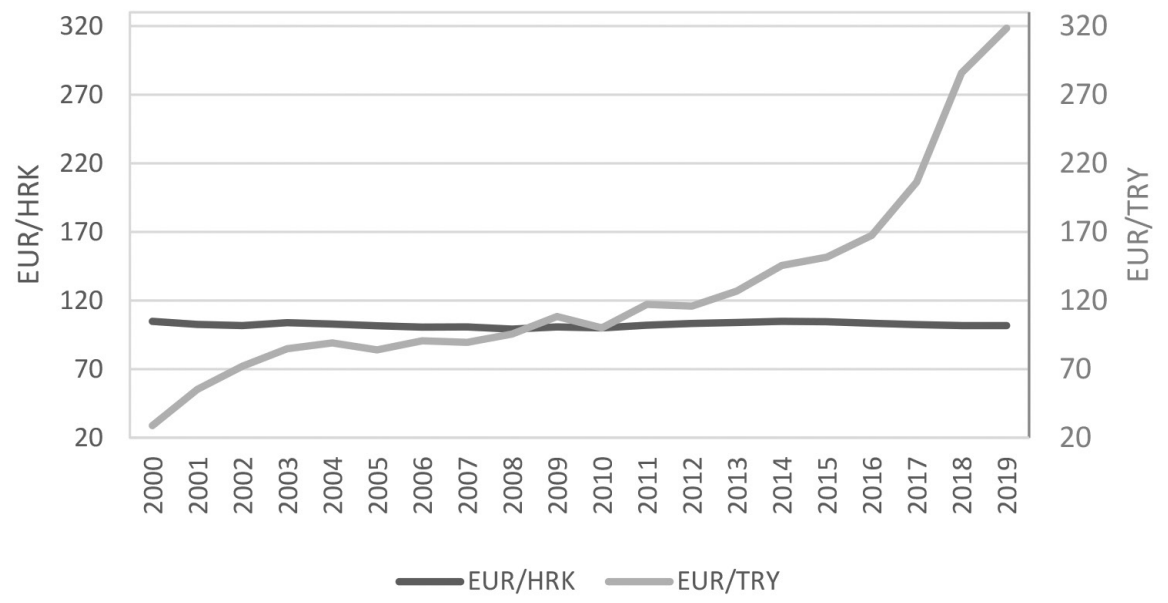

Figure 23. Nominal exchange rates of Turkish lira and Croatian Kuna against euro (yearly averages)

Sources: Croatian National Bank, Eurostat

\subsection{Inflation Measured by Consumer Price Index}

The consumer price index (CPI) represents the weighted average of prices of a basket of consumer goods and services consumed/used by an average urban consumer. Since CPI is used as one of deflators of nominal effective exchange rates to obtain real effective exchange rate, a measure of cost competitiveness that also affects tourism indicators, Figure 24 shows inflation developments in Croatia, Turkey and Euro Area.

What is easily seen is that throughout the analysed period Turkey recorded higher rate of sustained increase in general level of prices in comparison to Euro Area, where significant share of its visitors come from. Rise in CPI inflation in recent years in Turkey reflects nominal exchange rate pass through (due to import dependence of its economy), but also political context and elevated risks.

On the other hand, Croatia experienced relatively stable and low inflation, with the period average in the interval 2000-2019 amounting to 2.1\%. Both countries' (as well as Euro Area) rise in inflation in 2008 reflect exogenous shock deriving from increased prices of commodities on the global market, notably crude oil prices. 


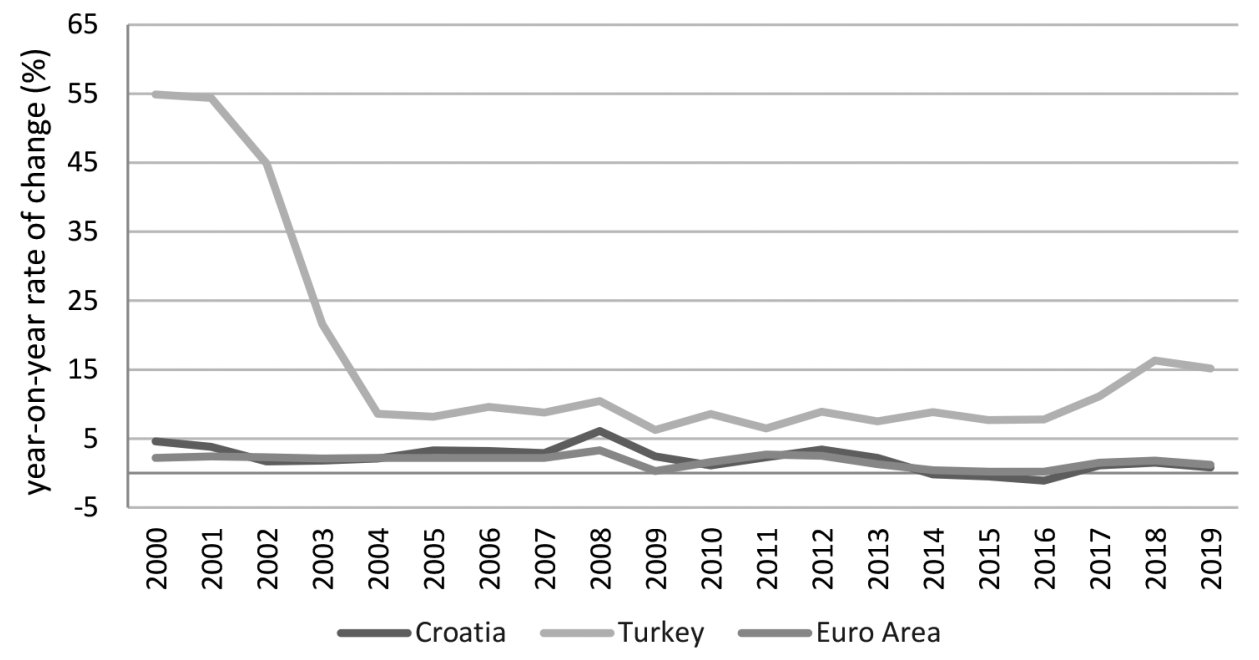

Figure 24. Consumer price index (2000-2019)

Sources: Turkish Statistical Institute, Croatian Bureau of Statistics, Eurostat

\subsection{Real Effective Exchange Rates}

The real effective exchange rate adjusts the nominal effective exchange rate for the effects of relative prices (foreign partners and domestic, in the paper deflated by $\mathrm{CPI}^{7}$ ). A fall in the real effective exchange index indicates real appreciation (foreign basket of goods and services buys less of the domestic basket of goods and services, indicative of a loss in price competitiveness), while the increase in real effective exchange rate points to real depreciation (foreign basket of goods and services buys more of the domestic basket of goods and services, indicative of an increase in price competitiveness). Since real exchange rates affect the purchasing power of foreign visitors they weigh on their willingness and drive to visit certain countries.

Figure 25 reveals that the real effective exchange rate in Croatia appreciated (strengthened) before the eruption of global financial crises, while in the period following the crises to 2015 it depreciated (weakened). Since 2016, the real effective exchange rate for Croatia remained broadly stable or marginally appreciated, which mirrored both inflation differentials and nominal exchange rates dynamics. Despite unfavourable recent movements in real effective exchange rates, during the past few years, Croatia recorded an increase in numbers of arrivals and nights spent by foreign tourists, as well as an increase in financial proceeds from tourism. ${ }^{8}$

When it comes to Turkey, the real effective exchange rate showed a pattern similar to Croatia's until 2015. In the interval from 2001 to 2005, Turkey's real effective exchange rate significantly appreciated thus pointing to erosion of price competitiveness. From 2005 to 2012, though volatile, the real effective exchange rate was relatively stable. Sustained depreciation of real effective exchange rate in Turkey has been observed since 2011 and was especially pronounced in 2017 and 2018, its dynamics influenced in the mentioned period by nominal depreciation of Turkish lira (Figure 23) and CPI movements (Figure 24). The ensuing increase in purchasing power of foreign visitors had a positive impact on foreign tourist arrivals and foreign tourist nights spent in Turkey (see Figure 1 and Figure 2).

\footnotetext{
7 In order to get indicators of price competitiveness, nominal effective exchange rates can be deflated either with consumer (CPI) or producer price index (PPI). In order to get an indicator of cost competitiveness, nominal effective exchange rates are usually deflated by unit labour costs (ULC).

8 Thus indicating the importance of security perception and non-price competitiveness.
} 


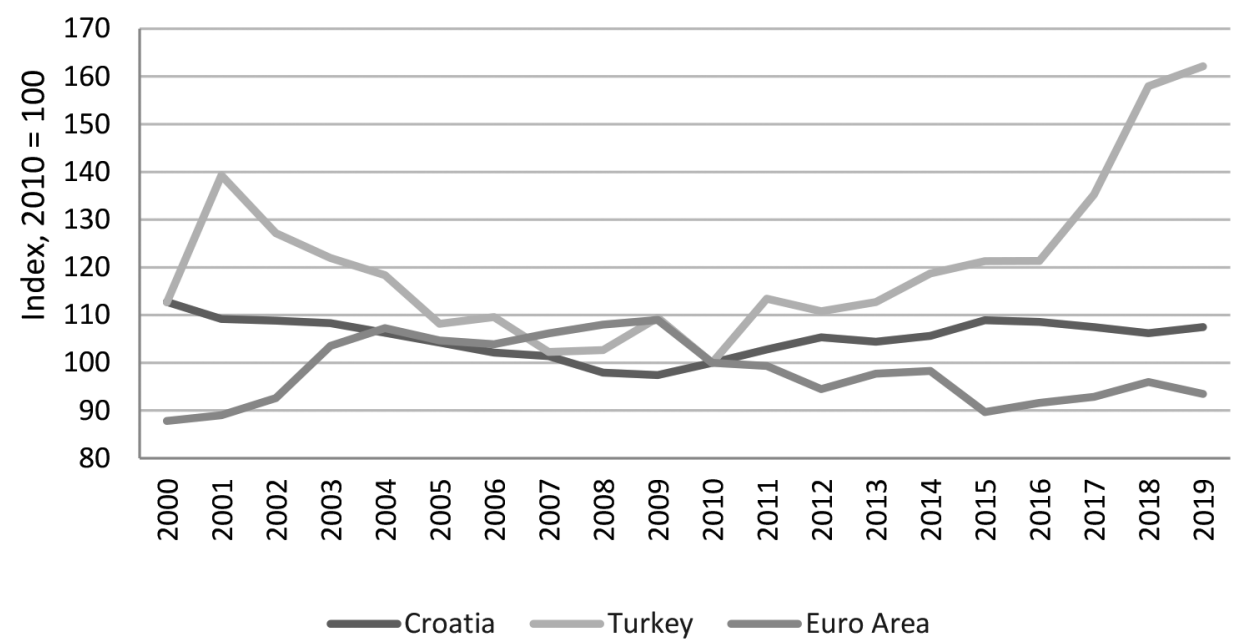

Figure 25. Real effective exchange rates deflated by CPI (2000-2019)

Sources: Central Bank of Turkey, Croatian National Bank, Eurostat

\subsection{Capital Investments In Travel and Tourism Sectors}

Capital investments in travel and tourism industries include capital investment spending by all industries directly involved in the travel and tourism sectors. Capital investments and sound development strategies (next chapter) boost the development and future prospects of the sectors and thus contribute to the overall real economic growth in the medium-run (Khan et al., 2020).

Figure 26 shows that both Croatia's and Turkey's investments in travel and tourism sectors constitute a significant part of total investments. After the volatile period before the global financial crisis, in Croatia, the mentioned share amounted to around $10 \%$ of total investment. Turkey recorded higher shares of two sectors' investments in the period before the escalation of global financial crisis (peak in 2001) and in the aftermath of the crises the very share stabilised at around $7 \%$, with a slight drop observed in recent years.

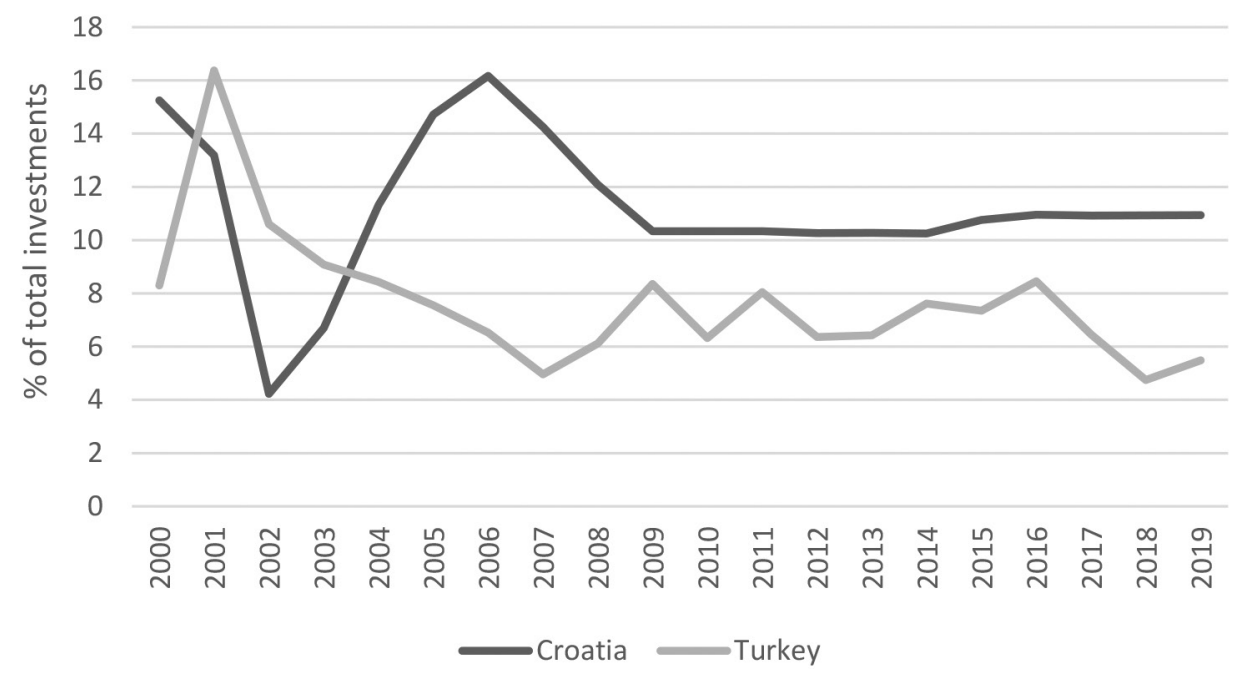

Figure 26. Capital investments in travel and tourism sectors

Sources: World Travel and Tourism Council, Croatian National Bank, Eurostat 


\section{FUTURE PROSPECTS: TOURISM DEVELOPMENT STRATEGIES}

\subsection{Tourism Development Strategy of Croatia}

According to Croatia's Ministry of Tourism, the official tourism development strategy's goals ${ }^{9}$ are to elevate the competitiveness and make Croatia recognisable as an international tourist destination, mainly by improving the quality and the content of activities on offer and establishing Croatia on the global tourism market through successful promotion and marketing campaigns. According to the Ministry of Tourism, this goal will be achieved through the "development of tourism content and quality on offer" and through "successful promotion". By increasing and diversifying the contents of tourism activities offered the aim is to attract a wider array of people with different interests. The strategy also states that Croatia has the potential to achieve $24 \%$ more nights spent by 2025 compared to 2020. The expected annual growth in average expenditures per foreign visitor is estimated at $11 \%$. As for the accommodation facilities, the prediction is that in 2025 there would be approximately 1,1 million beds available of which $22 \%$ would be in hotels, $26 \%$ in camps, $39 \%$ in family accommodation facilities while the remaining $13 \%$ pertain to the rest of the commercial accommodation facilities (Croatia's Tourism Development Strategy, 2013).

To achieve the mentioned goals, the Ministry of Tourism needs to create a more diverse supply of activities and adjust the current operating approach (from current sun-and-sea to future allyear approach) to remain competitive on the tourism market. This can be achieved by stimulating investments in recreational and health tourism in the interior of Croatia, which is starting to gain more popularity over the past years while also promoting unique local culture and traditions which are different in every region of Croatia. The inclusion of small local wine and food producers into the mix will also prop up the development of tourism activities on offer and emphasize the aspect of authenticity (Christou, 2012).

One activity that Croatia is behind concerning some of its Mediterranean competitors is the golf segment. In this respect, Croatia's Ministry of Tourism (Action Plan for Golf Development, 2017) states that country aims to build 30 new and high-quality golf courses that will attract golf players and create additional interest for visiting Croatia.

Although Croatia's Ministry of Tourism is the most responsible and influential actor when it comes to overall tourism strategy and management, other tourist organizations should also participate and add value in activities whose aim is to promote and popularize Croatia on the international tourism map. "Tourist organizations significantly contribute to society promoting national beauty, cultural and historical heritage as well as broad geographical and national diversity" (Barišić and Marić, 2012). Croatian Tourism Association thus aims to increase "competitiveness, employment and overall positive contribution to the Croatian economy" by communicating with decision makers and partnering with investors (Croatian Tourism Association Website, 2019). Travel agencies also play a crucial role in promoting famous Croatian destinations by providing organized tours and travel arrangements for tourists.

An indispensable element of a good long-term development strategy is risk managing, and mitigating models and plans. Mikulić et al. (2016) suggest that Croatia should focus on the "risk of

Tourism Development Strategy of the Republic of Croatia published in 2013 applicable till 2020, and Strategic Plan of the Ministry of Tourism published in 2019 applicable till 2022. Both documents contain longer term projections. 
bad tourist experience", "the risk of terrorist attacks" and "the risk of bad weather". The authors claim that these risks "are not unlikely to occur, and, at the same time, they might exhibit a significant influence on inbound tourist flows".

\subsection{Tourism Development Strategy of Turkey}

Turkey's Ministry of Culture and Tourism is responsible to maintain, develop, protect, evaluate and promote the tourism sector of Turkey. Besides, in 2019, Turkey Tourism Promotion and Development Agency (TGA) was founded to promote Turkey as a brand with its tangible and intangible cultural, biological, or human-made heritage assets in the domestic and international markets. As the tourism sector contributes significantly to Turkey's real GDP, the Ministry of Culture and Tourism developed strategies and policies to increase the tourism revenues of the country. On the national level, the tourism sector is repeatedly highlighted as one of the main sectors to be developed both in the New Economy Programme of Turkey and the 11th Development Plan which encompasses the 2019-2023 period (OECD Tourism Trends and Policies, 2020). The country will try as well to increase the average spending of an international tourist and to raise the number of average nights spent.

Tourism Strategy for 2023 also envisages a total utilization of Turkey's historic, geographic, natural and cultural assets to leverage various tourism activity segments within the country. Accordingly, in addition to sea-sand-sun tourism, Tourism Strategy for 2023 aims to further develop golf tourism, health and thermal tourism, winter sports, ecotourism, cruise ship and yacht tourism, rural and conference tourism, thus addressing behavioural changes and travelling demands of modern domestic and foreign tourists. Moreover, Turkey's Tourism Strategy for 2023 emphasizes drawing the "Taste Map of Turkey" in order to create a gastronomy route for the visitors. The same strategy also targets to reach emerging markets in the Far East and Pacific regions, in order to welcome more international tourists from China, Japan, South Korea and India. As a result, intense and diversified marketing activities are planned to be conducted on TV, magazine and outdoor as well as on digital and social media.

The provision of the Tourism Strategy of Turkey 2023 is to implement strategic efforts by enhancing the cooperation between public and private sector governance. Tourism Strategy of Turkey 2023 also emphasizes terminating inequalities of the regions as well as developing additional employment opportunities in near future.

\section{CONCLUSION}

Both Mediterranean tourist destinations, Croatia and Turkey differ in geographic location and size, their historic and cultural identity. Croatia is a European Union member state near its major emitting tourist markets (Germany, Slovenia, Italy, Austria, Poland), with the big share of its foreign visitors relying on the country's (and neighbouring countries') modern highway and road connections. Only several tourist areas on the Adriatic littoral attract a higher share of air-borne international tourists (notably the city of Dubrovnik and Island of Hvar), and, in the continental part, capital Zagreb. Due to its location and excellent domestic (notably Turkish Airlines, world-renowned flagship carrier) and international (all year or seasonal, regular or chartered) air connections, the amount of air-borne passengers to Turkey is much bigger compared to drive-in foreign guests. Most visited destinations are dispersed along the Aegean and the Mediterranean Sea, as well as the city of Istanbul. 
Supply side tourism indicators included in the paper show that both countries rely heavily on hotel accommodation facilities, though Turkey more so when compared to Croatia. Turkish hotels in five and four-star rated categories, measured by the average number of beds offered, are also bigger than comparable Croatian hotel facilities. Another defining characteristic of Turkey's offer is hotel and resort all-inclusive packages, often sold at competitive prices. Both countries recorded a decline in low quality (notably two-star rated) hotel establishments which is corroborated by take-overs and significant domestic and foreign direct or portfolio investments in this industry. Besides hotels, Croatia relies on supply of holiday and other short-stay micro accommodation facilities owned predominantly by households, which are of much less importance in Turkey. Along the Adriatic coast Croatia offers a sizable number of camping grounds and, more recently, the country expanded its capacity in hostel facilities. Other physical indicators reveal that golf tourism is much more established and developed in Turkey, while the same is true for Croatia in terms of nautical tourism.

Demand side indicators point to sustained increase in number of arrivals and nights spent in both countries since 2010. Indicators for Turkey in this segment are more volatile and temporary drop in 2016 and 2017 is mostly attributable to shocks that ultimately affected security perceptions. On the other hand, Croatia's physical indicators gained a significant boost once the country joined the EU. Intra-year distribution of nights spent and number of arrivals shows that both countries rely heavily on the sun-and-sea concept of tourism, though Turkey's summer season seems to be less concentrated and of longer duration.

When it comes to the country of residence, Croatia's dominant foreign visitors in 2019 arrived from neighbouring or close-by countries - Germany, Slovenia, Austria, Italy and Poland. At the same time, the biggest share of Turkey's visitors in 2019 came from Russia, followed by visitors from Germany, the United Kingdom, Ukraine and Poland. Country of origin distribution is also mirrored in cross-border entry distribution. The share of drive-in foreign visitors dominates in Croatia (on average 90\% compared to $20 \%$ in Turkey), while share of fly-in guests dominates in distribution for Turkey (on average $77 \%$ compared to $6 \%$ in Croatia).

Both countries have comparative advantages in tourism, but Croatia relies on it in terms of gross domestic product formation more than Turkey. Accordingly, travel revenues in Croatia amounted to 19\% of GDP in 2019, whereas only to around 4\% of GDP in Turkey. Differences in the number of employed persons are not pronounced, with both countries' share of employment in accommodation and food service activities of around 6\% of totally employed in 2019 .

Selected competitiveness indicators point to much less volatile nominal exchange rate and subdued inflation dynamics in Croatia compared to Turkey. Fixity of Croatian kuna reflects macro but also idiosyncratic characteristics of small and open Croatia (notably ingrained and pervasive two-sided euroisation and high foreign currency denominated external debt). Depreciation of Turkish lira against euro (and other major currencies) and ensuing pass-through on domestic prices, which was especially pronounced in 2017 and 2018, mirrors the domestic political, economic and security-related issues. As determinants of the real effective exchange rate, nominal exchange rates and general level of domestic and foreign prices affect price competitiveness, dynamics of which have an impact on foreign visitors' purchasing power and ultimately travel decision making. Both Turkey and Croatia lost price competitiveness before the global financial crisis, while their effective exchange rate depreciated since the crises. Due to the nominal exchange rate movements of the Turkish lira, foreign visitors' purchasing power raised significantly, which helped the surge in physical indicators in recent years. On the other hand, though Croatia's real effective exchange rate slightly strengthened (appreciated), in the last four 
years the country recorded on average $10 \%$ yearly increases in financial proceeds from tourism, thus corroborating, in general, the value of marketing, non-price competitiveness and the importance of security perceptions.

Though Turkey's and Croatia's absolute and relative to GDP investments in travel and tourism sectors are impressive (on average $7 \%$ and $10 \%$ of the total investments, respectively), there are clear bottlenecks and areas for improvements in the mentioned sectors. Tourism development strategies of both countries indicate there is sizeable room for improvement in the approach, scope and scale of the industry. Croatia thus aims to build up in the future its higher value added tourism content and offer, as well as to prolong the duration of its high season. Turkey's tourism strategy similarly emphasizes the goals of further strengthening yacht and ecotourism, health and thermal tourism, and its winter sports offer.

The Mediterranean and global tourism competition are tough and realisation of such gains in Turkey and Croatia will require focus, determination and financial support, but, looking long-term, even more so the sense for sustainability and respect for green development. Accordingly, both countries should aim to expand and revise existing strategies and adapt them to the changing market conditions, paying even more attention to ecology, security and health issues.

\section{REFERENCES}

Akcay, Ü. and Güngen, A. R. (2019) The making of Turkey's 2018-2019 economic crisis, Working Paper, No. 120/2019, Hochschule für Wirtschaft und Recht Berlin, Institute for International Political Economy (IPE), Berlin.

Barišić, P. and Marić, I. (2012) The role of management as a strategic tourism guideline-Case of Croatia. International Journal of Business and Management Studies, Vol. 1(2).

Bozgeyik, Y. and Yoloğlu, Y. (2015) The Relationship Between GDP and Tourism Income in Turkey: 2002-2014 Period The Journal of International Social Research, Vol. 8, No. 40.

Christou, L. (2012) Is it possible to combine mass tourism with alternative forms of tourism: The case of Spain, Greece, Slovenia and Croatia, Journal of Business Administration Online, Vol. 11(1), pp. 1-8.

Cihangir, M.E., Erkan, B. and Harbalioğlu, M. (2014) The Effect on Current Account of net Tourism Revenues in Turkey, European Scientific Journal, Vol. 10(13), pp. 47-65

Esen, Ş. and Uyar, H. (2016) Competitiveness of Tourism and The Evaluation of Turkey According International Tourism Competitive Criteria, Research Gate, Accessible Link: https://www.researchgate.net/publication/228466565.

Genç, R. (2018) The Future of EU-Turkish Tourism Relations under the Shade of Brexit, Acta Universitatis Danubius, Vol. 14, No. 5.

Gerede, E. (2010) The Evolution of Turkish Air Transport Industry: Significant Developments and the Impacts of 1983 Liberalization, Yönetim ve Ekonomi, Vol. 17, No. 2, pp. 63-91.

Ivandić, N., Kunst, I. and Telišman-Košuta, N. (2015) Konkurentnost hrvatskog turizma: Stanje, odrednice i aktivnosti unaprjeđenja, Ekonomski fakultet Sveučilišta u Rijeci, pp. 71-87.

Mikulić, J., et al. (2018) Strategic crisis management in tourism: An application of integrated risk management principles to the Croatian tourism industry, Journal of Destination Marketing \& Management, Vol. 7, March 2018, pp. 36-38. http://dx.doi.org/10.1016/j.jdmm.2016.08.001

Orsini, K. and Ostojić, V (2018) Croatia's tourism industry: Beyond the sun and sea, Directorate General Economic and Financial Affairs (DG ECFIN), European Commission, No. 36.

Yeldan, A. E. and Ünüvar, B. (2015) An Assessment of the Turkish Economy in the AKP Era, Research and Policy on Turkey. 
